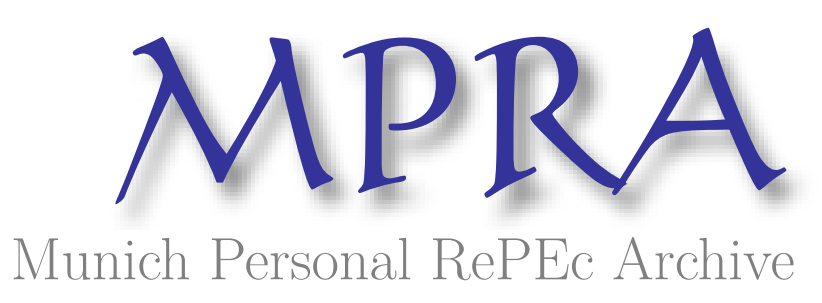

\title{
Corruption, Governance and Security: Challenges for the Rich Countries and the World
}

Kaufmann, Daniel

October 2004

Online at https://mpra.ub.uni-muenchen.de/8207/

MPRA Paper No. 8207, posted 10 Apr 2008 14:10 UTC 
CHAPTER 2.1

\section{Corruption, Governance and Security: Challenges for the Rich Countries and the World}

DANIEL KAUFMANN, World Bank Institute ${ }^{1}$
Traditionally, national governance and corruption challenges have been seen as a) particularly daunting in the poorer countries, with the richer world viewed as example or benchmark, b) anchored within a legalistic framework and focused on the quality of formal institutions, c) a problem of the public sector, and d) divorced from global governance or security issues, which are regarded as separate fields.

In this chapter we challenge these notions, by attempting to portray a more complex reality of mixed governance performance, not only in most of the emerging world but also among the richer countries of the Organization for Economic Cooperation and Development (OECD). ${ }^{2}$ We suggest that the undue emphasis on narrow legalism has obscured more subtle yet costly manifestations of misgovernance, which afflict not only poor but rich countries as well. The traditional notion of corruption is challenged, and a broader framework of analysis is proposed. In particular, where the "rules of the game" have been captured by the elite, frequently ignored manifestations of so-called "legal corruption" may be more prevalent than illegal forms, such as outright bribery, which are the usual focus of attention. By scrutinizing the under-emphasized institution of "influence," including vested interests, influence peddling, and outright capture by the elite, we arrive at some unconventional conclusions.

Available data indicate clearly that ethics and corruption represent a challenge not only for many emerging economies, but also for many countries of the rich world. In fact, there is enormous variation of ethical standards within the rich world itself, more broadly defined to encompass forms of corruption that may not be strictly illegal, such as undue influence on public policy—through political funding or other means - by a few powerful interests.

Probing the question of unequal and undue influence requires an examination of the role of the private sector, both domestic and transnational, and their interactions with public sectors, both at home and abroad. It is, therefore, important to study patterns of bribery, as practiced by firms operating abroad, in order to understand the interface between corporate governance by powerful transnationals and governance within the public sectors of emerging economies. Our analysis suggests that bribery abroad by transnationals headquartered in rich countries continues to be a serious issue in emerging markets.

In order to assess the relative importance of legal and illegal forms of corruption, in which many in the corporate and public sectors in both rich and emerging countries appear to be involved, we have carried out an empirical analysis of the data emerging from this year's Executive Opinion Survey (EOS) of the World Economic Forum. In particular, we present in this chapter a new set of ethicsrelated indices constructed from the various specific EOS 
questions on bribery, legal corruption and corporate ethics, which provide the empirical backbone to our conviction that many rich countries also have serious problems with ethics and corruption. We also present a comparison of the measures on obstacles to business reported by firms participating in the EOS (de facto variables) with traditional objective indicators (de jure variables). These data from the firms on the ground and its analysis are significant for identifying the real obstacles facing the business community, since we found that governance and corruption issues constitute key constraints to investment and business and are particularly significant in assessing a country's overall competitiveness.

In order to provide an initial framework of governance linkages that cut across national borders, we must bridge the traditionally separate issues of national governance and global and domestic security. We challenge the notion that these security issues are not subject to measurement, and based on an analysis of the EOS data, empirically review the relative importance and links between global and domestic governance aspects of security, focusing on common crime, organized crime, money laundering, and the cost of terrorism threat. From our analysis of the firms' reports, it is clear that a number of countries in the rich world have serious domestic problems with undue influence-even capture-as concern key public policies, laws and regulations, in addition to the more recent onslaught of security threats. The mere fact of strong traditional rule-of-law institutions, as is the case in the G-7 and other rich countries, guarantees neither level playing fields - i.e. freedom from influence peddling - nor protection against terrorism.

\section{Sobering evidence: Corruption and misgovernance worldwide}

In our chapters in two earlier publications of the Global

Competitiveness Report (Kaufmann, 2002, 2003), we reviewed the evidence on the trends of governance and corruption worldwide, and on its costs. In these earlier papers, we pointed out that the evidence from the past ten years or so did not indicate improvement on key dimensions of worldwide governance, in contrast to the marked improvements in some other important policy areas, such as the attainment of relatively stable macro-economic policies in most countries.

Revisiting the long-term trend evidence from the most recent EOS, we find that, overall, this stagnating trend does not appear to have been reversed over the past year. While significant upward changes are unlikely in longer-term institutional issues, there appears to be some variation in trends across country groups. Notably, even if there is still a substantial governance gap between the two groups in many dimensions, there are some hopeful signs for emerging economies in certain governance aspects, in possible contrast with the wealthier OECD countries.

For example, in Figure 1, we see the EOS ratings given by firms on the control of judicial bribery since the late nineties, showing, somewhat surprisingly, that the perception of this phenomenon by executives in the rich countries has deteriorated, while improving somewhat in the new industrializing countries (NICs) of east Asia, ${ }^{3}$ as well as in emerging economies. The assessment of judicial bribery in Latin America is less dire than it was last year, although it remains very low, and still below the average for all emerging economies. However, while this year's data suggest that there may be some early signs of potential convergence between the rich countries and emerging economies, the extent of the disparity in this and other traditional dimensions of corruption-particularly various forms of bribery-between OECD and emerging economies is large. Moreover, there is significant variation within regions and groups of countries. For example, Figure 1 also shows that the new tigers of east Asia (NICs) have approached the standards of the rich countries, while the middle-income Latin American countries rate well below the NICs, and even the emerging economy average.

\section{Obstacles to business startup: Regulatory governance}

A key insight that has emerged in the empirical study of governance in recent years, thanks in large measure to the analysis of the rich survey data from the EOS, is the importance of unbundling manifestations of corruption and governance. This implies that it is misguided to generalize, based on the assessment of one particular governance dimension, or of an average for the country. This is because there are large variations in governance quality and performance across different dimensions. In this chapter we probe more deeply into the analysis of variation across different governance dimensions, and focus more closely than in the past on the performance of the rich countries. By showing the trend over time in the ease of entry to enterprises, Figure 2 provides insight into a rather different challenge to businesses, related to the regulatory regime component of governance. The evidence reveals that the striking gap is not between the rich countries of the OECD and the emerging economies overall - in fact, on average, the gap is not very large between both group averages - but between particular sub-regions.

First, it should be noted that firms in the NICs of east Asia report fewer obstacles to business entry than those in rich OECD countries, reflecting the highly regulated nature of economies in some OECD countries. ${ }^{4}$ The gap between the east Asian NICs, on the one hand, and Latin America-as well as the surveyed countries of the former Soviet Union, which also score poorly-on the other, is particularly acute, reflecting once again the magnitude of 


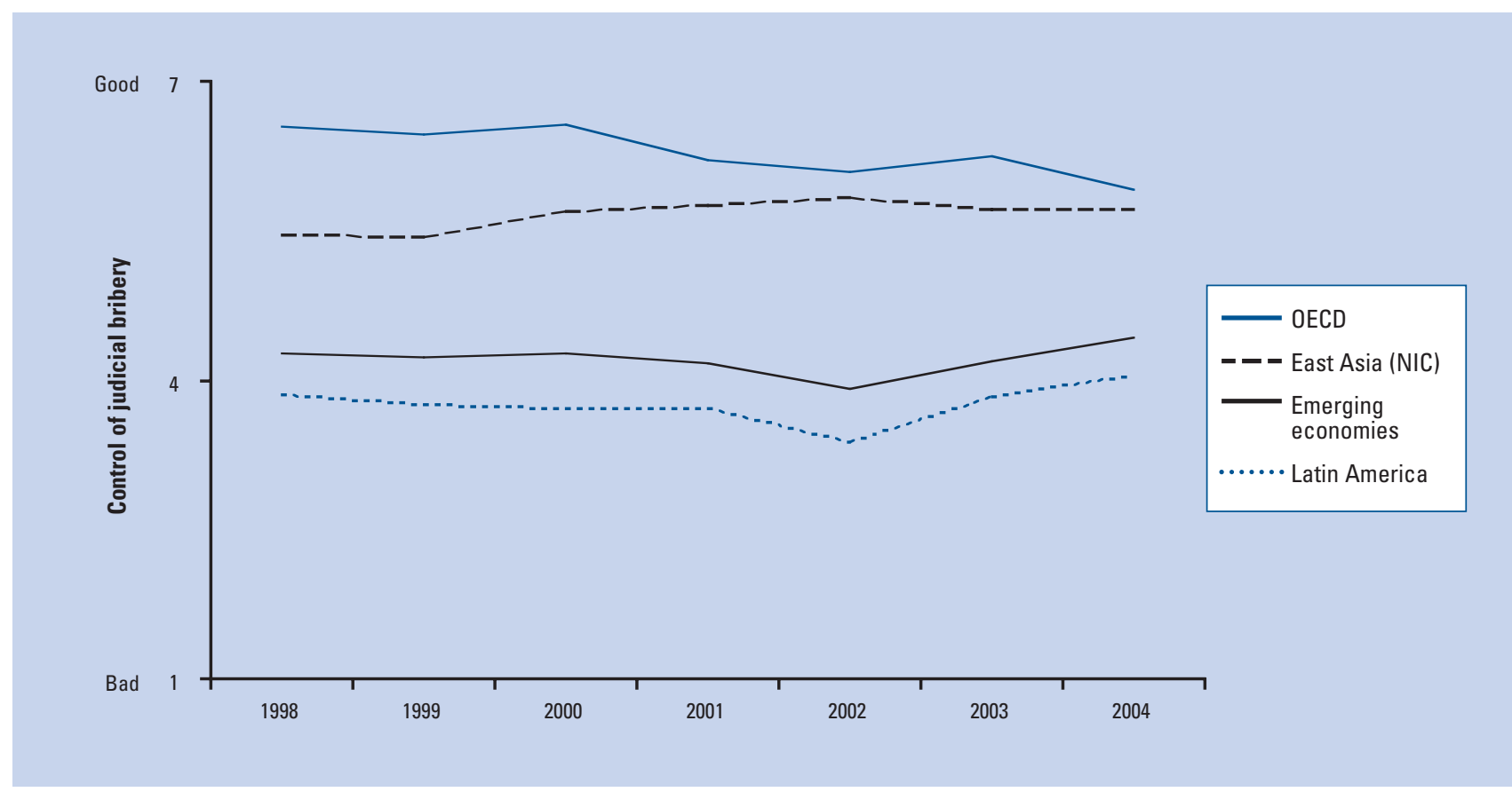

Source: EOS 1998-2004 question: "In your industry, how commonly do firms make undocumented extra payments or bribes connected to getting favorable judicial decisions? commonly/never occur."

the institutional and investment climate challenges faced by many countries in Latin America.

At the same time, there are also rather telling gaps among different subgroups of the rich countries of the OECD, challenging the traditional notion of bundling them as a uniform block. Although not shown in the figure, the data indicate that firms in the Nordic countries report exemplary ease of entry, in sharp contrast to the countries of southern Europe, which report greater restrictions on business startups than for Eastern Europe, even more restrictive than for developing countries.

Broadening the specific glimpse we provided above into the problems reported by firms on the regulatory regime, and exploiting the richness of the EOS survey, we undertook a more microeconomic analysis, exploring links between competitiveness, the business climate, and governance. The EOS survey data from firms themselves provide a window on what is taking place on the ground (de facto), to complement, and also challenge, assessments based on official statistics or information of an administrative or legal (de jure) nature. As suggested earlier, this microeconomic analysis of governance obstacles reveals particular challenges also afflicting countries in the OECD.

Some may react to Figure 2, showing firms' own reports on the ease of entry for enterprises in their country, by pointing out that such data are more telling about the conventional business climate than about governance.
Furthermore, those who are keen to dismiss the sobering information provided by the EOS data tend to equate enterprise responses with unreliable perceptions, not mirroring what actually takes place in reality. In fact, as both survey and statistical techniques have improved, it is increasingly possible to make cautious inferences from data emerging from a large number of enterprise responses. While an element of perception will undoubtedly remain, these perceptions are shown to be important, since firms' own assessments of the quality and characteristics of the surrounding business climate do shape their own business and investment decisions. ${ }^{5}$

A useful exercise to codify the regulations required to set up a firm was recently carried out by the "Doing Business" (DB) project at the World Bank (2003), based on information provided by lawyers in many countries. This exercise, based on "objective" indicators, in contrast with what the EOS data suggests, revealed that an overall improvement in the regulatory environment faced by enterprises has recently taken place. We were then able to conduct a comparative analysis, utilizing the following objective variables: the number of days needed to start a business, the minimum capital requirement, and the index of complexity in starting a business. This constitutes the de jure data. At the same time, as shown in Figure 2, we have the more subjective data from the firms themselves, on how they see the obstacles to business entry on the 


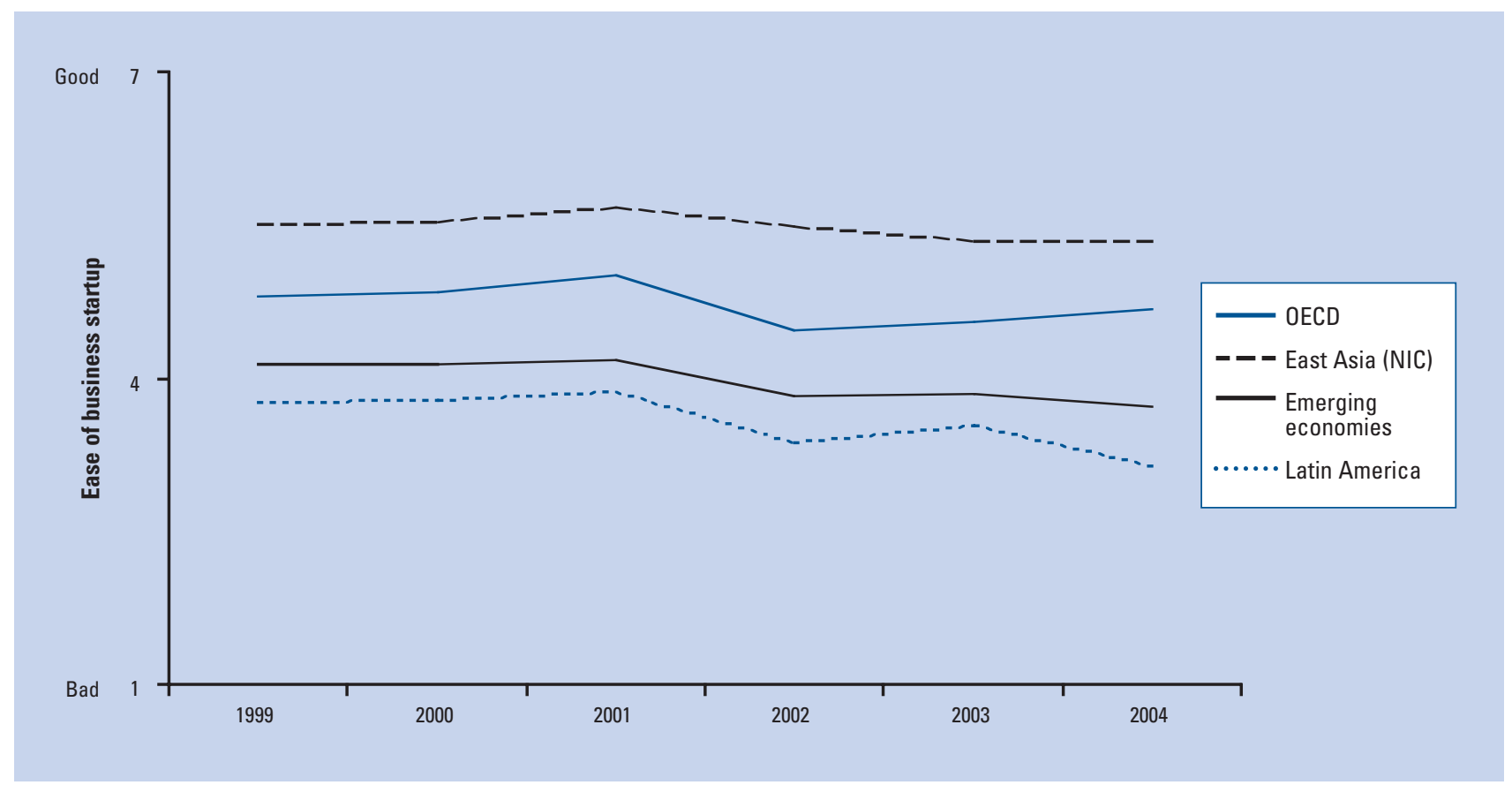

Source: EOS 1999-2004 question: “Starting a new business in your country is generally extremely difficult / easy." Ease of business startup (dependent) variable taken from EOS 2004. Number of days, minimum capital, and complexity index to start up a business, taken from the database in "Doing Business in 2004" (World Bank, 2003). Control of corruption, taken from worldwide aggregate governance indicators for 2002 (Kaufmann et al. 2003).

ground. This data, along with other variables from the EOS, constitutes what we could call the de facto data. How do the de jure and de facto data relate to each other?

We set up a simple econometric exercise, presented in Table 1, to explain the de facto perceptions of the firms emerging from the EOS data, taking into consideration the de jure information on administrative requirements.

First, we inserted only one variable at a time, from the de jure database, and asked how well it tracked the actual EOS reports from the firms on the ground. In fact, we found that there are severe limits to the extent to which the "objective" de jure data explained the de facto firm reports. We found that the de jure indicator of the number of days required to start a business was related, to some extent, to the subjective EOS response on the ease of starting a business. Yet the resulting correlation is not large: only about 20 percent of the variation in the de facto EOS response variable is explained by this objective de jure variable.

Furthermore, the de jure variable for minimum capital requirements has no explanatory power-a zero correlation, in fact-with the de facto variable. Finally, the de jure variable, measuring the complexity of starting a business performs somewhat better than the others we reviewed, explaining, on its own, about one third of the variation on the "ease of entry" (de facto) variable reported by the firms. Yet even in this case most of the variance is left unexplained. Thus, an alternative one ought to consider is whether the de facto variable, based on the firm reports, is actually capturing a key dimension of the policy and regulatory "implementation on the ground", since the actual implementation outcomes are not measurable from the de jure information, based as it is on a priori information, on what is on the books, in legal statutes or official statistics. ${ }^{6}$

Consequently, in order to assess the real impact on the firms' reports concerning ease of entry, we expanded the test, to include variables measuring the quality of governance in the implementation of policies and regulations. For this, we included an indicator (from outside the EOS variables) measuring corruption in the regressions, complementing the de jure variables discussed earlier. We found that when both the de jure and de facto sets of variables were included, the magnitude and significance of the de jure coefficient, as well as its explanatory power, declined further. By contrast, the corruption indicator stayed almost as strong as when it was correlated alone against the ease of entry variable. ${ }^{7}$ In short, governance factors appear to be extremely important in explaining the firms' reported ease or difficulty in starting up a business; in fact, they appear to matter more than the particular number of official steps required.

These results are operationally relevant, and are not merely a statistical or academic exercise. First, they suggest an important reason for systematically collecting and 
Table 1: de facto vs. de jure regulatory measures: econometric results explaining actual ease of business startup

Dependent variable: ease of entry (EOS 2004)

\begin{tabular}{|c|c|c|c|c|c|c|c|c|c|}
\hline Number of days to start business (DB ‘04) & -0.012 & - & - & - & -0.006 & - & - & -0.01 & 0.00 \\
\hline t-stat & $4.90^{* * * *}$ & - & - & - & $2.36^{* *}$ & - & - & $2.11^{* *}$ & 1.48 \\
\hline Minimum capital to start a business (DB `04) & - & 0.01 & - & - & - & 0.03 & - & - & - \\
\hline t-stat & - & 0.31 & - & - & 一 & $1.73^{*}$ & - & - & - \\
\hline Complexity of starting business (DB ‘04) & - & - & -0.14 & - & - & - & -0.07 & -0.12 & -0.05 \\
\hline t-stat & - & - & $6.86^{* * *}$ & - & - & - & $2.88^{* * *}$ & $4.96^{* * *}$ & $1.90^{*}$ \\
\hline Control of corruption (KK 02) & - & - & - & 0.57 & 0.48 & 0.57 & 0.41 & - & 0.39 \\
\hline t-stat & - & - & - & $9.80^{* * * *}$ & $7.97^{* * *}$ & $9.28^{* * *}$ & $5.64^{* * *}$ & - & $5.50 * * *$ \\
\hline Number of (country) observations & 94 & 94 & 94 & 104 & 94 & 94 & 94 & 94 & 94 \\
\hline Adjusted $R^{2}$ & 0.20 & -0.01 & 0.34 & 0.44 & 0.47 & 0.45 & 0.48 & 0.37 & 0.49 \\
\hline
\end{tabular}

Notes: ${ }^{* * *}=1$ percent statistical significance; ${ }^{* *}=5$ percent statistical significance; ${ }^{*}=10$ percent statistical significance.

analyzing survey data such as the EOS, since these reported perceptions provide significant information on the quality of institutional implementation on the ground. Second, they caution against over-reliance on official, "objective" statistics on business/investment climate issues, which ignore key issues of implementation on the ground. Thus, although objective measures can also be valuable, they should be supplemented by measures capturing the reality of how rules, regulations and policies are implemented on the ground. Finally, these results point to the fact that governance issues are critical for the business environment.

Indeed, one of the key obstacles to ease of entry by firms, namely corruption, is, in itself, a core governance variable. Investment climate and business development issues cannot be narrowly viewed, merely by counting the number of legal or regulatory steps, and without understanding the institutional context within which such regulations and policies are formulated-including the vested interests that shape them-and implemented. The nature and quality of institutional and policy formulation and implementation in this area is, in fact, strongly anchored in governance, and in many countries corruption may be a particular hindrance to enterprise development, the business climate, and competitiveness. Next we turn to an empirical examination of this issue, based on the new EOS data.

\section{Significance of governance for the business climate and competitiveness: The view of the enterprise}

We have suggested that listening to the reports of firms can provide valuable information and insights. In this section, we probe more deeply into the views of the firm about the main constraints they face, as reported in their answers to a simple and telling question at the end of the EOS survey instrument: "From the following list (of 15 obstacles), please select the five most problematic factors for doing busi- ness in your country, and rank them from 1 (most problematic).

Figure 3, segmenting the sample between OECD and emerging economies, depicts the frequency of the leading constraints listed by each firm. For emerging countries, they were seen to be corruption, bureaucracy, policy instability and financing, while for the wealthy countries of the OECD, the leading obstacles were labor regulations, bureaucracy, and taxes.

When organizing the fifteen listed constraints around seven key institutional and policy clusters, the governance cluster, comprising corruption and bureaucracy, emerges as the most binding constraint, on average, worldwide, and was named as one of the top three constraints by firms in 79 out of the 104 EOS sample countries. Although the clusters of finance, labor markets/human capital, tax regime and infrastructure also pose significant obstacles in many countries, they lag far behind the governance cluster. Figure 3 also shows that at the other extreme of the spectrum, the macroeconomic policy cluster, represented by foreign exchange regulations and macro-economic instability/inflation, no longer figures as a priority constraint to the enterprise sector. ${ }^{8}$

The World Economic Forum's Growth Competitiveness Index (GCI), which rates the relative competitiveness of all EOS countries, has been one of the key contributions of the GCR over the years. There are several ways to analyze the possible key determinants of country competitiveness, as measured by the GCI, but any viable analysis would have to account for the pitfalls of confusing simple association with clear causality, or of equating fundamental determinants of competitiveness with an observed empirical link between the GCI and current variables, which may simply reflect a quasi-tautology. The latter is because the GCI is, in itself, a composite of many current EOS and external variables. ${ }^{9}$

For this simple empirical inquiry, we focused instead on the above-mentioned informative synthesis question to each firm about the top constraints to their business, 


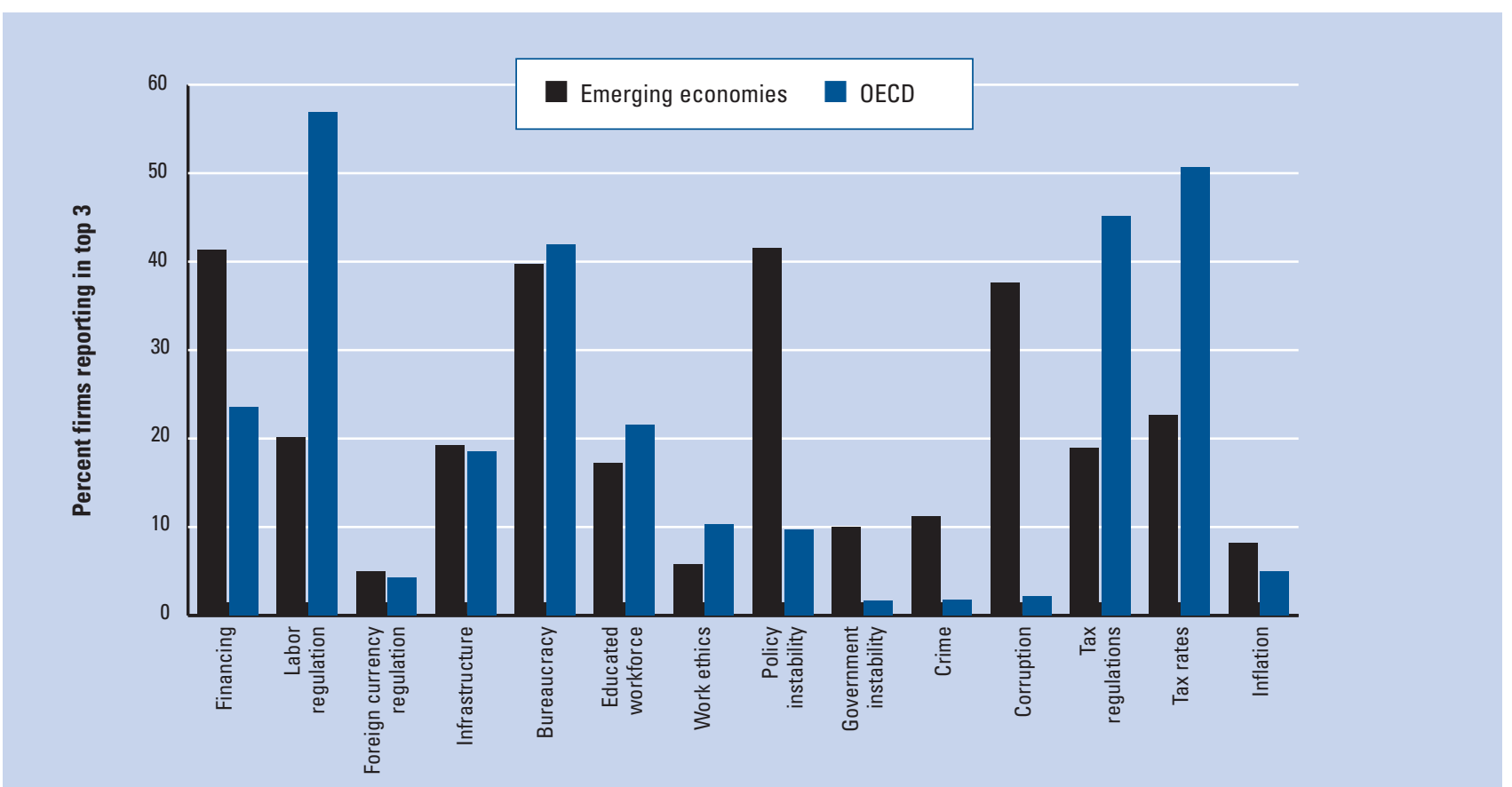

Source: EOS 2004 question: "From the following list (including all constraints depicted in the figure) please select the five most problematic factors for doing business in your country, and rank them from 1 to $5 . "$

which has no input role in the construction of the GCI. We have seen that firms in many countries responded that some constraints, especially those in the governance dimension, have a direct bearing upon business. But does this necessarily imply the loss of a country's competitiveness edge? We probed statistically the link between the various constraints to business given by the firms, on the one hand, and the GCI for the country, on the other. First, we performed simple correlations between the extent to which each potential constraint poses a significant obstacle to business and the GCI ranking. By far the highest correlation, at -0.76 , was between the corruption constraint and the GCI.

But this result does not control for other factors. In principle, it could be that in some countries there are many (more than five) significant obstacles to doing business, and corruption may be proxying for such omitted factors. Therefore, we also performed regression analysis where all 15 constraints were included in the specification, as potential determinants of the GCI. The results are synthesized in Figure $4 .{ }^{10}$ For each constraint we depict paired columns, reflecting two alternative specifications: the left side of each paired column depicts the results of the impact of the shown constraint on competitiveness, holding all other constraints constant (as controls), while the columns on the right side-in addition to holding all other constraints constant-further controlled for the country's per capita income.

Under either scenario, the importance of tackling corruption in order to improve a country's competitiveness appears to be clear. A country that manages to reduce the extent of corruption as an obstacle to business by one standard deviation can expect on average, to move up about 30 rank positions - if income per capita is not maintained at a fixed level—or, more conservatively, about 20 rank positions if income per capita is held constant. The latter is indeed a conservative assumption, since it has already been empirically shown that improved governance results in higher incomes per capita. But even under this conservative scenario, the potential payoff for a country's competitiveness of addressing corruption as an obstacle to enterprise appears to be very large indeed. In fact, based on the actual responses by firms worldwide to the list of 15 obstacles, removal of no single other obstacle would come close to offering such a large payoff for improving a country's GCI standing. ${ }^{11}$

But could this particularly striking finding be simply the outcome of the poor country-rich country global divide, capturing the "fact" that the poorer countries have a larger corruption problem than the richer ones? It was in order to address this very question that we controlled for the country's income per capita level in the specifications, for which the results are shown in Figure 4. We then 


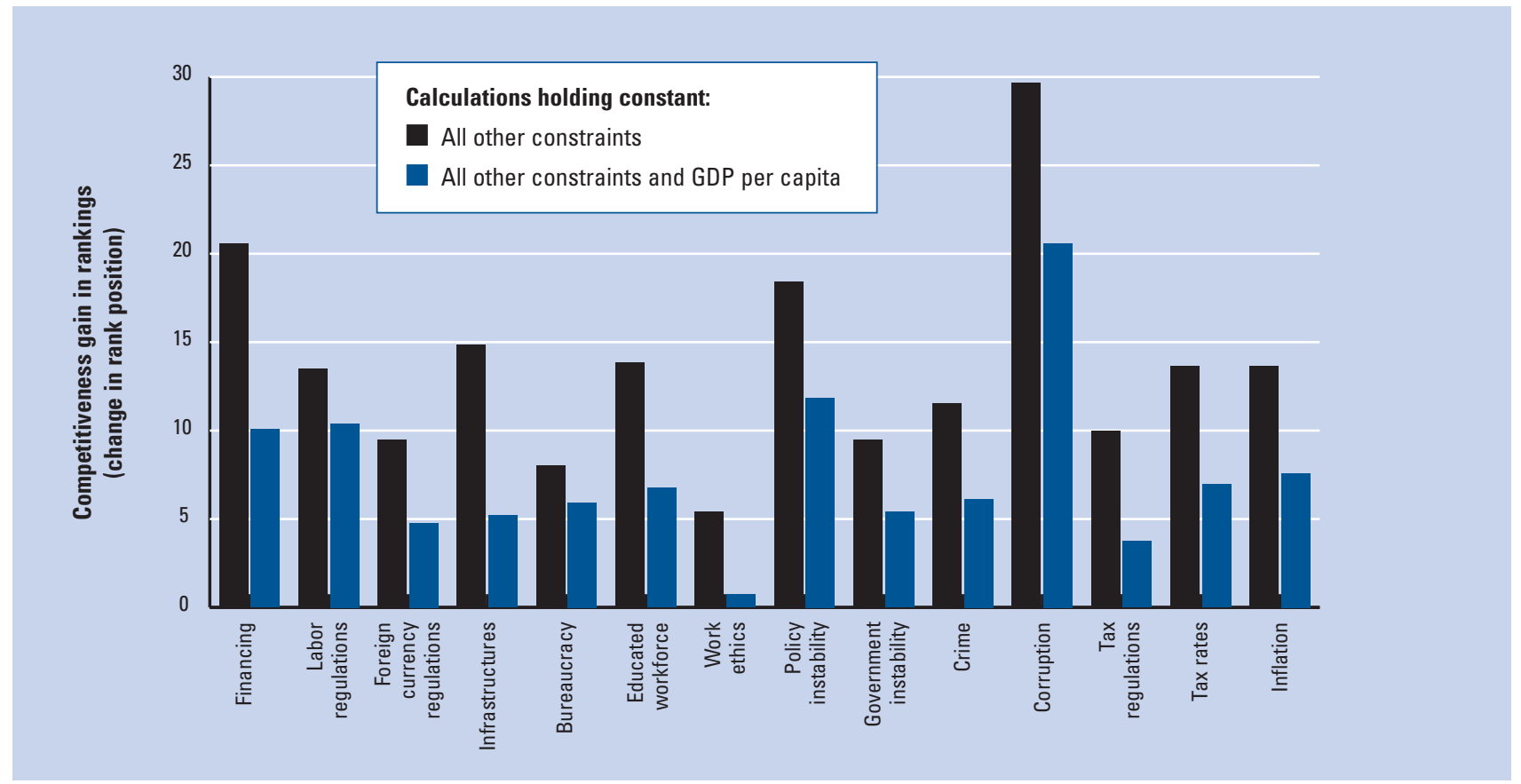

Source: Constraints to business data based on EOS 2004 question: "From the following list, please select the five most problematic factors for doing business in your country, and rank them from 1 to 5 ." GCI based on GCR team calculations for 2004/2005 Report; GDP per capita from World Bank. Calculations based on regression estimates of the impact on the $\mathrm{GCl}$ of an improvement in the constraint by one standard deviation.

performed an additional test, segmenting the sample and reviewing whether the primacy of the impact of corruption on GCI would apply, if one concentrated on the higher income countries. Indeed, even if one concentrates on only the top half of the EOS country sample, in terms of income per capita, the resulting magnitude and significance of the control of corruption constraint to its impact on the GCI is very similar to that of the full sample. ${ }^{12}$

At the core of this finding is the fact that there is significant variation among middle- and higher-income countries as regards the quality of governance in general, and in the control of corruption in particular. While richer countries tend to exhibit less prevalence of blatant and illegal forms of corruption, the wealthier countries, including many in the OECD, do face challenges related to corruption and misgovernance. We next probe some of these issues more closely.

\section{Is the rich world a paragon of good governance and corruption control?}

Much recent study of governance and corruption has been based on the simple empirical observation, using available worldwide indices, that, on average, richer countries are perceived to be much less corrupt than poorer developing countries. ${ }^{13}$ The undisputed serious governance and corruption challenge faced by most emerging economies may have encouraged a sense of complacency in the richer world - and within it the OECD_regarding corruption and misgovernance. Moreover, such relative comparisons presumed a lack of interdependency, and thus ignored the potential role of OECD in setting standards of governance in emerging economies.

We attempted to make a modest contribution to reversing this perceived bias. Using comparisons based on our analysis of the EOS data for 2004, we suggest some of the strengths and weaknesses of the richer world, with regard to issues of governance and corruption.

Conventional wisdom points to low corruption within OECD countries. The first table in Kaufmann (2003) featured the average percentile ranks for each region, based on worldwide governance indicators. On average, OECD countries ranked at about the 90th percentile. However, these are averages, within a relative ranking, and the measures included in these indices relate to the standard definition of corruption, namely the abuse of public office for private gain. Hence, the focus is on the illegal nature of acts such as bribery, in order to illicitly derive private gain at the expense of the public.

Let us assess, however, whether even relatively satisfactory average rankings may mask problems within OECD countries, and whether some other non-traditional forms of corruption, may emerge as significant problems.

First, it is worth noting that, although this year's EOS provides some support for the notion that traditional 
corruption levels in OECD may not be very high-particularly as regards domestic bribery payments-even this relatively low bribery percentage can translate into sizeable absolute amounts. This is due to the sheer economic might of OECD countries, which account for about 80 percent of the world's output.

Second, while the average in relative terms is not high, there is substantial variation within OECD countries. The long-standing OECD members from southern Europe exhibit higher levels of bribery prevalence than the tigers of east Asia, or of some emerging countries in other regions, such as Chile, or Slovenia, other new EU members from Eastern Europe, and, in some dimensions, Botswana in Africa. The high variation within the OECD is illustrated by the fact that the gap in the prevalence of bribery between the exemplary Nordic countries, on the one hand, and southern Europe, on the other, is larger than the gap between southern Europe and the average for all emerging economies.

Third, there has historically been an epistemological and legalistic set of biases in the study of corruption, which, as hinted earlier, relies on a definition that, given today's realities and problems, begs an open challenge. Specifically, the traditional notion of "abuse of public office for private gain" has often been interpreted in a legal sense to mean committing an illegal act, and, more However, the reality of corruption is two-fold: first, it most often involves collusion between at least two parties, typically from the public and private sectors, for a corrupt act to take place; second, where the rules of the game, laws and institutions have been shaped, at least in part, to benefit certain vested interests, some forms of corruption may be legal in some countries.

For instance, soft forms of political funding are legally permitted in some countries, through the creative use of legal loopholes, and may exert enormous influence in shaping institutions and policies benefiting the contributing private interests, and at the expense of the broader public welfare. A similar problem is seen in favoritism in procurement, where, as we mentioned earlier, a transparent and level playing field may be absent, without necessarily involving illegal bribery.

Consequently, it is timely to explore a less traditional definition of corruption, one that accounts more broadly for the undue benefits derived by the private few from their excessive influence in shaping the institutions, policies, laws and regulations of the state to their own ends. Vested interests that remove public policy from the realm of democratic-i.e.contestable-decision-making should be an important component of this new definition. Undue influence by private vested interests on the state sector may, or may not, involve the exchange of a bribe or

related form of illegal corruption. In other words, room is thus provided, in this more neutral definition of corruption, for so-called legal forms of corruption, which can by defined simply as the "privatization of public policy." Such an alternative definition focuses on the key mediating institution or agent committing the abuse of power, namely the institution of (undue) influence, driven by vested interests. It also provides for neutrality in terms of the legality, or lack thereof, of the corrupt act itself.

Finally, it is neutral as regards the private or public nature of the sector players, implicitly recognizing the important and activist role of those in the private sector as well. In particular, it enables us to scrutinize the role of corporate ethics, in both its legal and illegal corruption dimensions, alongside the often-cited role of public sector ethics. In the following section, we present a simple empirical framework to translate these general notions into concrete and measurable indicators, to see what insights can be gained from the exercise.

\section{Establishing ethics indices}

We posited that corruption can be more broadly construed as attempts to exert undue influence in order to "privatize" public policy, and/or appropriate the provision of public services for private purposes. To assess the empirical applicability and validity of this general notion, we carried out a data exercise with the EOS dataset, which contains a wealth of answers to questions on various dimensions of corporate and public sector ethics and governance. We constructed indices to reflect ethics in the public sphere (executive as well as judicial/legal) and for the corporate sectors. Consistent with the previous discussion, inter alia, we captured in these indices the legal corruption dimension of corporate ethics, alongside its illegal counterpart. In fact, consistent with the analysis in this chapter, the focus in these ethics indices is on their honesty, integrity and corruption control dimensions. ${ }^{15}$

To construct these indices, each relevant individual governance question in the EOS was mapped to one index. Each set of input questions was averaged to create the respective ethics index. The theoretical range of each index is from 0 to 100 , reflecting the average percentage of firms in each country reporting a satisfactory situation on the particular ethics-related EOS question.

In brief, the main components and indices comprised the following:

i) the Corporate Illegal Corruption Component (CICC), measuring a) types of bribery, in which a private agent plays a key role (as in procurement, shaping regulations and policies), and b) the firm's own corporate ethics self-rating based on a question in the EOS); 


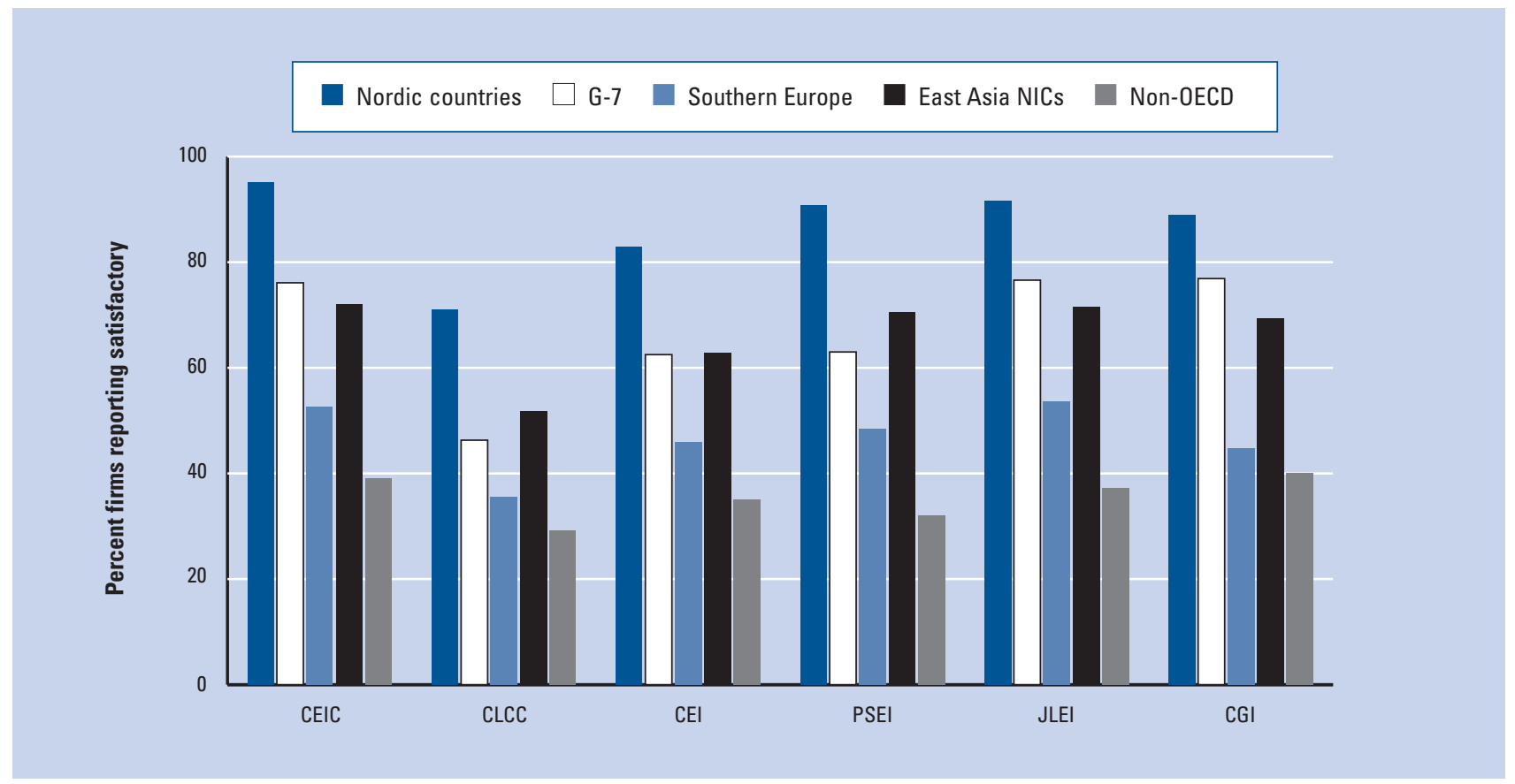

Acronyms: CICC: Corporate Illegal Corruption Component; CLCC: Corporate Legal Corruption Component; CEI: Corporate Ethics Index (the average of both legal and illegal corporate corruption components, CICC and CLCC); PSEI: Public Sector Ethics Index; JLEI: Judiciary / Legal Effectiveness Index; CGI: Corporate Governance Index. Source: Author's calculations based on EOS 2004. See the Appendix for detailed definition and inputs into each ethics index.

ii) the Corporate Legal Corruption Component (CLCC), measuring legal dimensions of undue influence, such as legal political finance; the particular influence of powerful firms on politicians and policymaking, etc;

iii) the Corporate Ethics Index (CEI), which represents the simple average of both the legal and illegal corporate corruption components in items (i) and (ii);

iv) the Public Sector Ethics Index (PSEI), measuring the variables related to public integrity, bribery and favoritism in the public sector;

v) the Judicial/Legal Effectiveness Integrity Index (JLEI), focusing on questions of effectiveness and integrity of the legal and judicial system;

vi) the Corporate Governance Index (CGI), based on standard questions (internal to the firm) regarding corporate governance, such as the relationship between board and management, etc.

The last index, for Corporate Governance (CGI), which does not fall within the realm of ethics properly interpreted, was constructed as a comparator from a traditional corporate field. The five other indices all share a clear focus on ethics. ${ }^{16}$
What do these indices show? The indices for a number of selected sub-regions are presented in Figure 5, from which we can observe that, consistent with the earlier findings on traditional illegal forms of corruption, it is misleading to generalize about all rich countries, simply by focusing on the average of the rich countries in the OECD. The first set of indices in Figure 5 focuses, in fact, on the illegal corruption component of corporate ethics (CICC). The gap between the Nordic and southern European countries is larger than that between the Nordic countries and the tigers of east Asia, or between southern Europe and the average for all non-OECD countries.

As one moves to an analysis of the legal corruption component of corporate ethics (CLCC, the second set of columns), the reality of OECD standards, on average, becomes even more disturbing. Again, that average masks large variations within the rich OECD countries: while the Nordic countries continue to excel, relatively speaking, the averages for the countries of the G-7 and southern Europe are rather low.

On the better side of the corporate legal corruption ethical spectrum, countries such as Norway, the Netherlands, Finland and Singapore all score in the midto high 70 s, indicating that the vast majority of the respondents regard their reality as satisfactory. On the legal corruption component of the corporate ethics index, the 
United States, in stark contrast, rates a mere 30, Italy 35, Spain, Portugal, France, and Canada about 40, and Japan 45-all below the emerging economies, such as Chile, Botswana, Colombia, and South Africa.

In short, the Nordics do well on this dimension of corporate ethics, but not so the G-7 and southern European countries. This points to the pitfalls of bundling the rich OECD countries as one homogeneous group. Indeed, it is telling that in this legal corruption component in particular, the tigers of east Asia perform better than the G-7 block. In fact, the OECD as a whole, and the G-7 in particular, perform much worse in this legal corruption dimension of corporate ethics than in its illegal counterpart.

This evidence on the extent of the problem of legal corruption in the G-7 and southern Europe is noteworthy, because the focus of international comparisons has, until now, been on the illegal dimension of corruption. This, in turn, has perpetuated the notion that there is a huge gap in ethical behavior between the first worldusually perceived as ethical across the board-and the third world, and has led to the neglect of the measurement and analysis of subtler forms of corruption. Clearly, in many of the heavyweight countries of the OECD, the powerful corporations exert extensive influence over policymaking. This recognition of the extent of undue influence by powerful elements in the corporate sector carries with it both domestic and global governance implications, as illustrated by the strong pressure to continue protecting trade in many rich countries. This, in turn, has been very costly to development of the emerging economies.

The third set of columns in Figure 5 presents the summary Corporate Ethics Index (CEI), as the simple average of the first two (illegal and legal) components. Not surprisingly, similar observations apply, indicating large discrepancies in corporate ethics performance within OECD countries and blocks, and the less-than-stellar performance on corporate ethics by firms in the G-7 and southern Europe. The fourth and fifth set of columns show the ethics index for the public (PSEI) and judicial/legal (JLEI) sectors, respectively. Here, it is noteworthy that the G-7 appears to rate relatively well in the Judicial/Legal Effectiveness and Integrity Index, but not as well for the executive side of the public sector. By contrast, the Nordics (at the top again), southern Europe, and the NICs of east Asia all rate their executive and judicial/legal sectors similarly. It is also evident that the emerging economies still face major problems in public sector ethics, as indicated by their rather low standing in the PSEI index.

The final set of columns, as a comparator, refers to the measurement in a simple index, of traditional notions of corporate governance (CGI). In this area, the G-7 rates relatively well, in fact, closing in on the Nordic countries. This relatively good quality of corporate governance also contrasts with the undue influence (legal corruption) component of corporate ethics, where we observe that the G-7-as well as a number of others in OECD—rate rather low. ${ }^{17}$

Next we assess a particular dimension of global interdependence. Having analyzed the behavior of enterprises in their home countries, we now turn to the question of how enterprises from the same countries behave and operate abroad in a globalized world.

\section{Bribing far from home}

Thanks to an international convention, firms from OECD countries have, for a number of years, been forbidden to engage in bribery overseas. With the US Foreign Corruption Practices Act (FCPA) in force for nearly thirty years, and the more recently adopted OECD Anti-Bribery Convention for about five years, it is worth exploring whether OECD firms operating abroad do, in fact, uphold ethical standards closely resembling those of their home or destination country. ${ }^{18}$ In fact, not long after the OECD Convention was in force, we provided a preliminary analysis of the firms' behavior abroad, based on a survey of firms in transition economies in 2000. For that region of the world, we found that at that time OECD firms were extensively engaged in bribery. ${ }^{19}$

A significant period of time has now elapsed, presumably permitting implementation to proceed on the OECD's Anti-Bribery Convention. Thanks to the EOS data, which cover all the regions in the world, it is possible to empirically revisit this question. The EOS collects information on whether firms operating in the surveyed country have headquarters abroad, and, if so, where they are located. Consistent with the OECD Convention, the focus of the brief inquiry reported here is on traditional forms of bribery, particularly, but not solely, on public procurement. From the analysis of the data on these transnational firms, comprising a significant portion of the sample, the following salient results emerged, summarized in Figures 6 and 7, measuring bribery at home and abroad, and procurement and administrative bribe fees, respectively.

The data show that transnationals (or multinationals, MNCs) operating abroad, within the OECD, exhibit behavior very similar to that of their domestic counterparts in the OECD home country. By contrast, those transnational firms headquartered in OECD countries, but operating in non-OECD countries, exhibit much lower (often illegal) corporate ethics standards, often more similar, in fact, to those of the recipient country. In Figure 6, the leftmost column (of the four representing each type of bribery) indicates the relatively low extent of bribery in the home OECD country, while the second column from left shows the relatively low incidence of bribery when operating in another OECD country. 


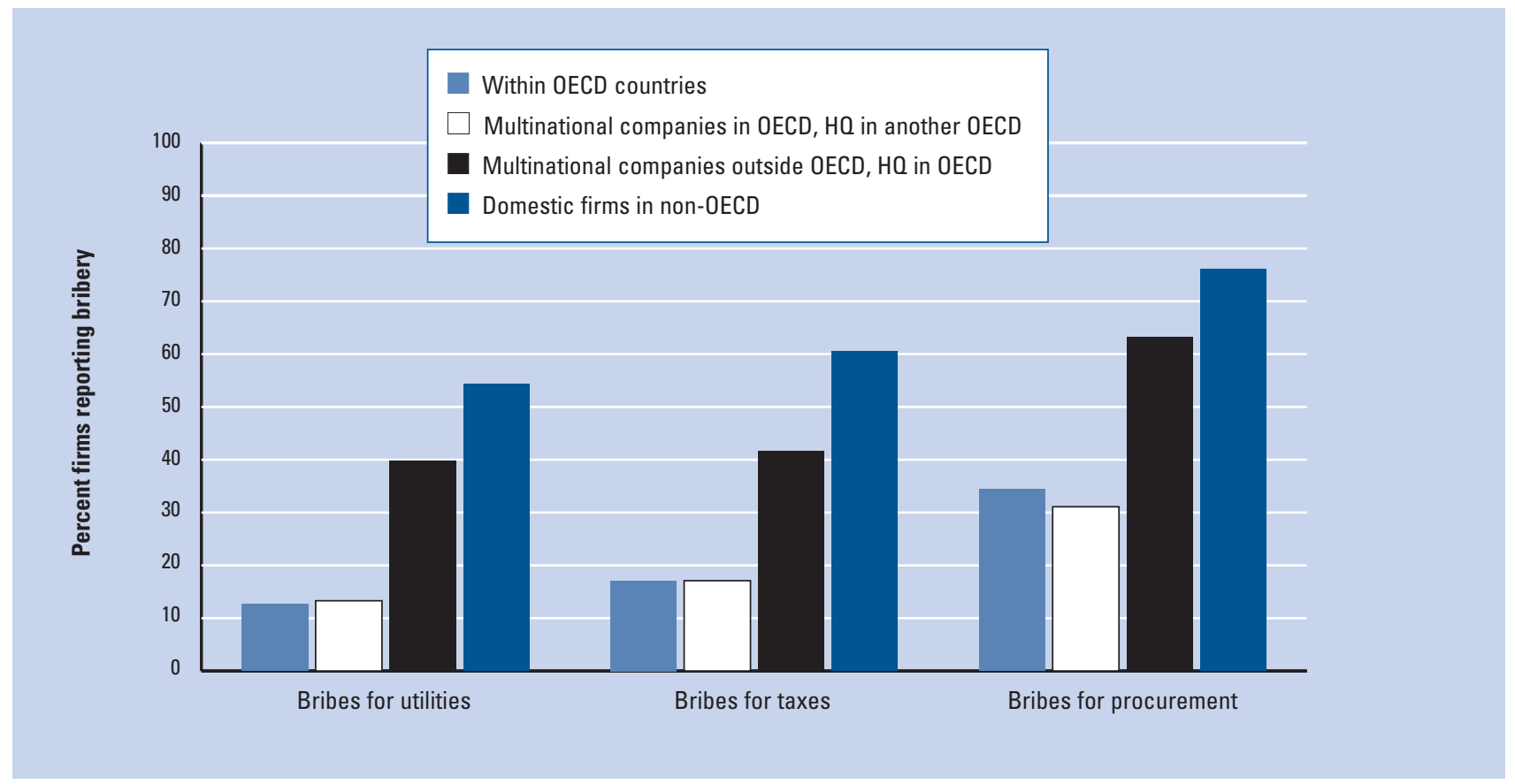

Source: EOS 2004. The percentage of firms reporting incidence of bribery within its group in the country is depicted in each case. EOS question on which these calculations are based: "In your industry, how commonly would you estimate that firms make undocumented extra payments or bribes connected with the following: public utilities, tax payments, awarding of public contracts? very common (1)/ never occur (7)". Any firms reporting answers 1 through 5 were considered to be reporting at least some frequency of bribery, while answers of 6 and 7 were not.

By contrast, the third column for each type of bribery presents the high prevalence of bribery by firms headquartered in a rich OECD country but operating outside the OECD. Rather than exhibiting practices consistent with many other (domestic) firms in the country of origin, in which they are headquartered, their behavior more closely resembles that of the domestic firms within the non-

OECD destination country itself (fourth column of each bribery type). These differences in bribery practice, often determined more by the characteristics of the destination country than by the country of origin, or by international legal instruments, appear to be aimed at public procurement, an intended focus of the OECD transnational anti-bribery convention.

Figure 7 shows a similar pattern, if one focuses on a quantitative assessment of bribery, whether of the bribe fee percentage paid by firms in public procurement (left side of each paired column), or of the overall share of bribes in the firm's annual revenues (right side of each paired column). Again, we see that firms headquartered in the OECD, operating outside of the OECD, are engaged in bribery to a larger extent than at home. In fact, their bribery levels may exceed those of the NIC firms at their home countries in east Asia. Thus, in spite of the years of implementation of the OECD Convention, it is apparent that there is an "adaptation" by many MNCs to the local bribery practices.
In this context, it is also interesting to note in the data that corporations in countries having a much longer history of transnational anti-bribery legislation, such as the United States, also appear to exhibit a large gap between their corporate ethics standards at home, as compared with those operating in countries outside the OECD. Such a gap between corporate ethics standards at home and abroad is apparent across all the rich OECD countries, even for those settings where they have exemplary standards at home, such as the Nordic countries. Indeed, the significant gap between corporate ethics behavior at home and abroad suggests the extent to which incentives are important; hence, adaptation to local institutional arrangements takes place.

Not all the evidence on transnational bribery points in the wrong direction, however. While the levels remain high, so is the gap between practices at home and abroad. An initial comparison of the frequency of bribery this year, as compared with last year, suggests that the prevalence of bribery may not be as high as it was last year. ${ }^{20}$ It is obviously too early to tell whether this is the initiation of a trend of improvements over the coming years.

Further, for such structural medium-term improvement to take place, it is worth pondering at this stage whether, in addition to exhortations, voluntary codes, and legal fiat, the incentives for improved corporate ethics practices abroad require fuller alignment. A focus on incentives, in 


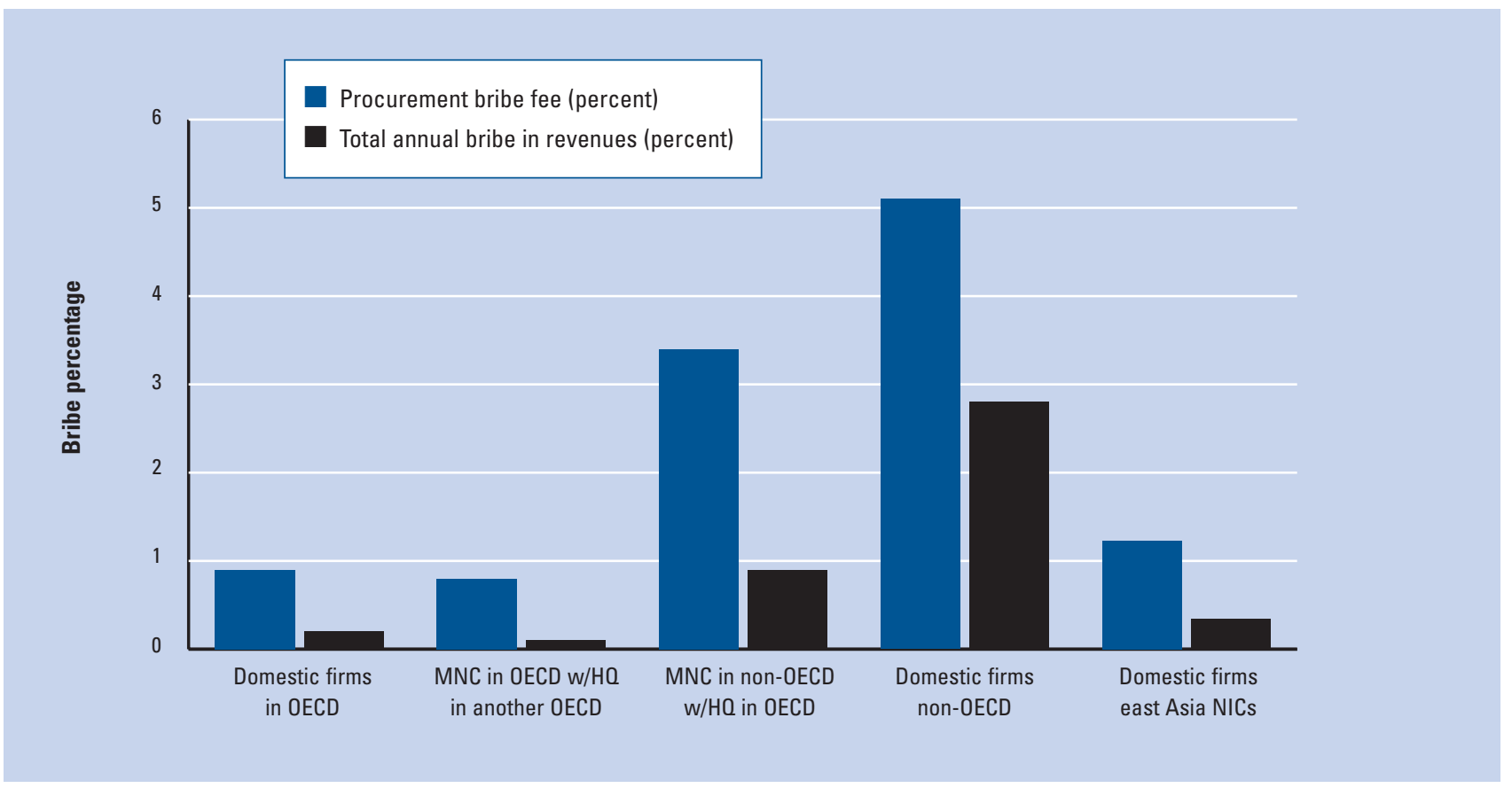

Source: EOS 2004 questions: i) for procurement bribe fee: "When firms in your industry do business with the government, how much (percent "fee") of the contract value must they offer in additional payments to secure the contract?" ii) for total annual bribes in revenues: "On average, what percent of total annual revenues do firms like yours typically pay in unofficial payments to public officials?" Inconsistent data were considered not applicable and not used. The data is subject to margins of error and thus not suitable for precise rankings.

turn, may require additional measures, to complement those already in place.

The rich countries of the OECD benefit significantly from trade, labor and human capital from the emerging economies. Similarly, the countries in emerging economies benefit from many economic linkages with their richer counterparts, and more generally from globalization. It goes without saying that there are areas where improvement is badly needed, such as those related to governance and to the corporate ethics of some MNCs abroad. Moreover, there are areas of close interdependence in today's world which entail particular costs and threats. One such area refers to security, where inter alia, data for empirical analysis has been lacking, impairing analysis and perpetuating misconceptions. We address this issue briefly in the next section.

\section{Security and crime: Global or domestic governance challenge for the rich world}

Given the type of governance and security challenges facing many countries today, it is pertinent to ask whether metrics and data analysis can shed light on the global and domestic security concerns being faced presently by the rich world, and their implications for governance. Security has been an area notable for the paucity of internationally comparable and reliable empirical statistics. We suggest a preliminary empirical analysis of elements bridging the traditionally separate issues of national governance and global and domestic security. We also challenge the notion that these security issues are not subject to measurement. ${ }^{21}$ In order to do this, we performed a limited analysis of the EOS data on the report by firms of the costs to business of terrorism, common crime and organized crime, as well as their reports on the prevalence of money laundering through the banking and non-banking (informal financial) sectors. Some results of interest emerge, summarized in the following.

i) The global nature of the threats and costs of terrorism As we observe in Figure 8, the costs of terrorism as reported by the enterprise sector appear to be similar, on average, for the key regions of the world. Each region reports a sizeable, if not extreme, cost of the terrorism threat. For instance, in Figure 8, it is interesting to note the contrast between the relative uniformity in regional averages of the perceived cost of the threat of terrorism, on the one hand, and the perceived cost of crime or state capture, which varies significantly from region to region, on the other. Terrorism is a globalized phenomenon. As we shall see next, however, this seeming uniformity of the 


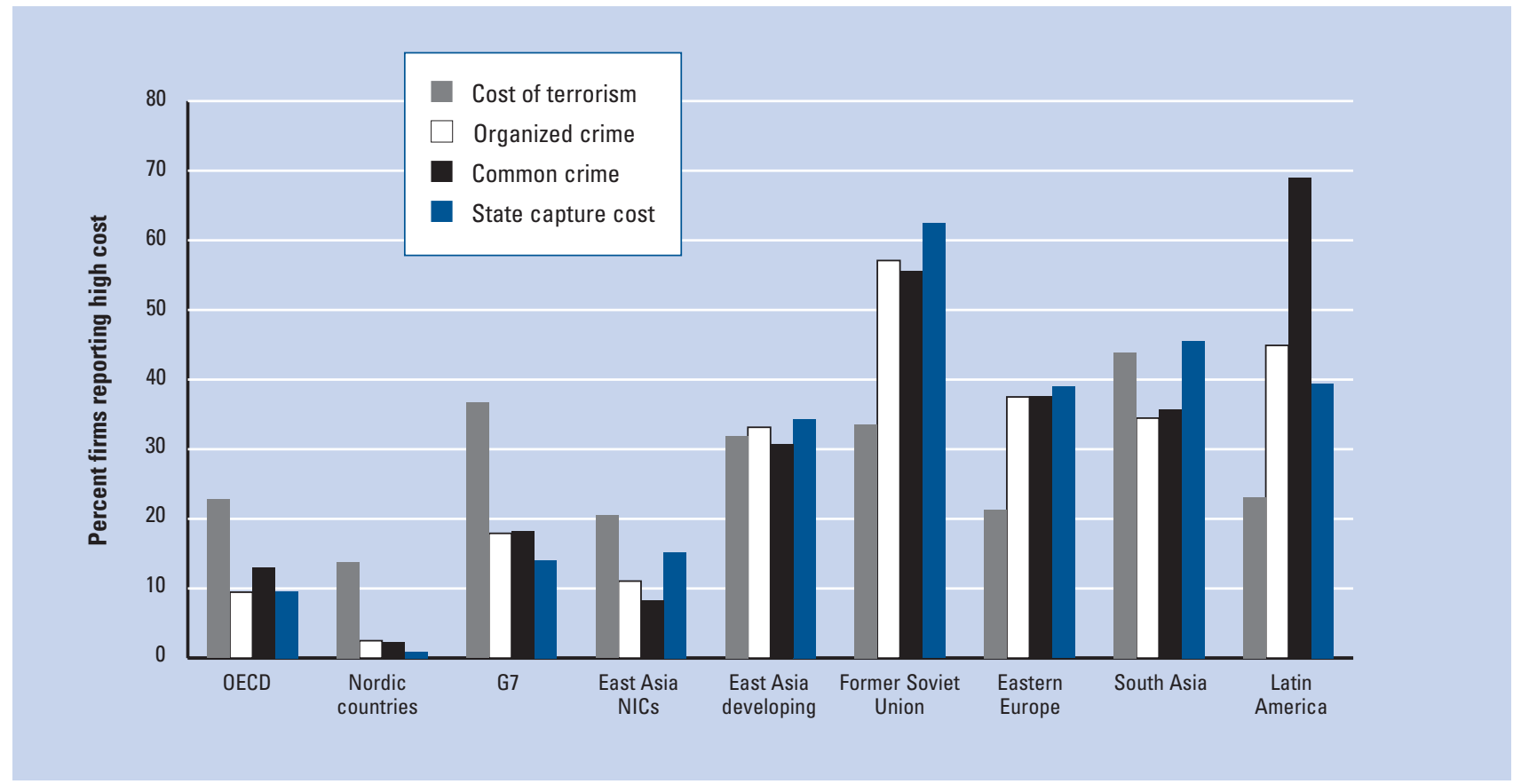

Source: EOS 2004 questions: i) "The threat of terrorism in your country, incidence of common crime and violence (e.g. street muggings, firms being looted), organized crime (mafia-oriented racketeering, extortion) in your country impose / do not impose significant costs on business?" ii) "In your country the diversion of public funds to companies, individuals or groups due to corruption is common / never occurs." A firm is considered as reporting high cost when rated the question as unsatisfactory $(1,2$, or 3$)$ on a scale of 1 to 7 .

perceived cost of terrorism ends at the regional comparative level and does not apply at the country level.

\section{ii) The challenge for some rich countries}

The reported threat of terrorism by firms in the rich countries is at least as high as the world average. Given the industrialized countries' generally high level of institutional development, this implies that the reported cost of the terrorist threat is high, as compared with other forms of crime. Thus, it is not surprising to observe, in Figure 8, that for the rich countries, on average, the terrorist threat exceeds the perceived cost of organized crime, of common crime, or of the impact on domestic competition of corrupt capture by powerful elite firms. In fact, there appear to be very significant differences within regions. Among the rich countries, as seen in Figure 8, there are sharp differences between the G-7 and the Nordic countries, between south Asia and the NICs of east Asia, and, among the former socialist countries, between the countries of the former Soviet Union included in the EOS and those of Eastern Europe.

Similarly, the differences in the perceived cost of terror across countries in a given region is striking. For instance, as shown in Figure 9, the cost of the terrorism threat as reported by the firms is significantly higher than the costs from organized crime in countries like the US, UK, Israel, Egypt, Spain, Sri Lanka, and Japan, while the contrary is the case in countries like Guatemala, Italy, Nigeria, Mexico, Ukraine and Venezuela. Countries such as Bangladesh, Colombia, and the Philippines face both problems acutely, according to the firms' reports; by contrast, neither of these security concerns seems to present itself in the reports from the Nordic countries.

iii) The level of development and quality of domestic institutions is weakly linked to terrorist threat, but strongly linked to other security challenges

The fact that terrorism has significant global aspects, in contrast to other problems, can be seen from the evidence summarized in Figure 10. First, to test whether the quality of domestic institutions may be a determining factor or not, we note that there appears to be a very low correlation between an effective parliament in a country and the reported perceived cost of the terrorist threat to that country. Even the correlation between the perceived cost of terrorism variable and the quality of the police in the threatened country is extremely low, as shown in the left half of the paired columns. This contrasts sharply with the close link between both organized and common crime, on the one hand, and the quality of domestic institutions, on the other. As we see in the right half of Figure 10, the correlation coefficient between the quality of parliament or the police, on the one hand, and the cost of organized crime in the country is about 0.7 (and similarly, although 
Figure 9: Firms reporting perceived cost of terrorism threat and organized crime: EOS 2004 (selected countries)

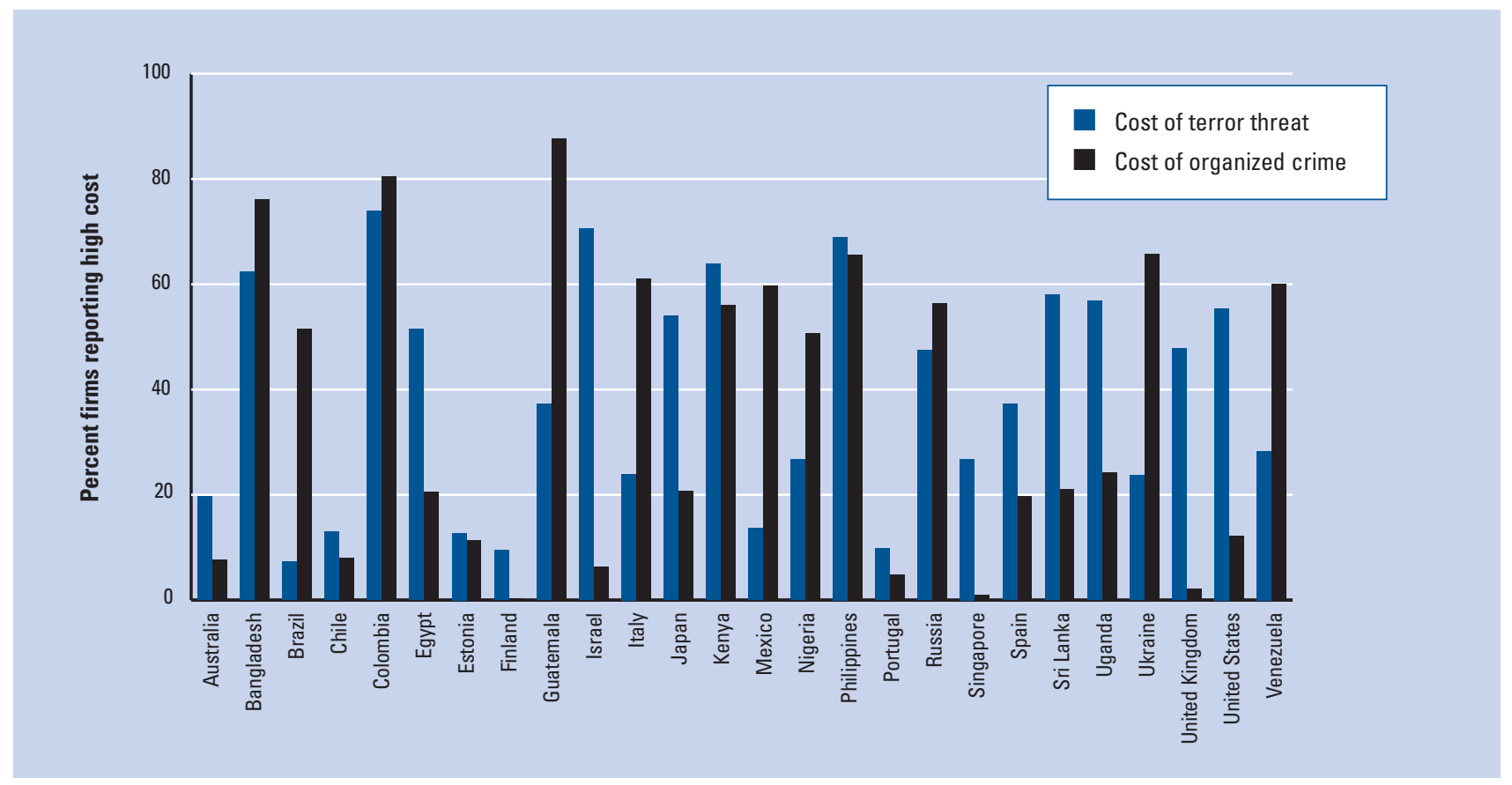

Source: EOS 2004 same questions as for Figure 8.

Figure 10: Relationship between threat of terrorism or organized crime and quality of domestic institutions

\section{Terrorism threat cost}

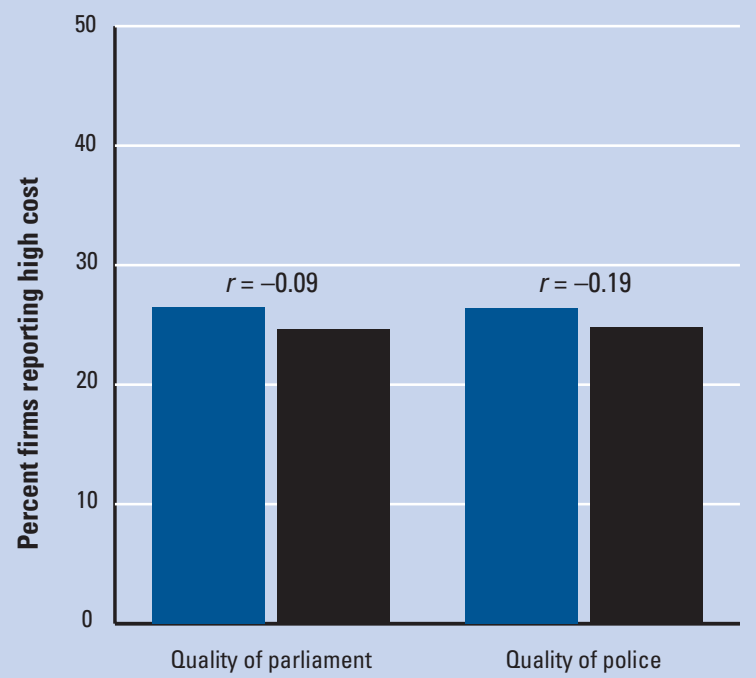

Organized crime cost

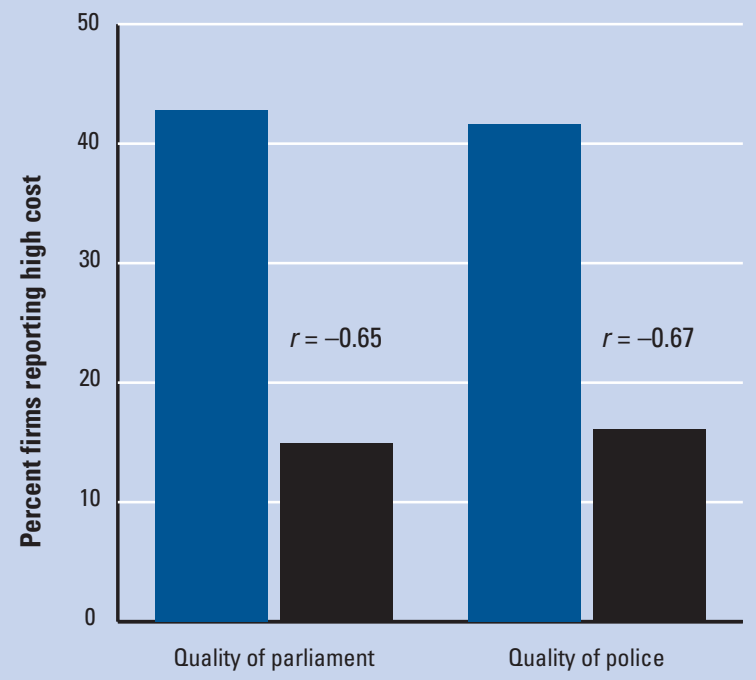

Low institutional quality

High institutional quality

Source: EOS 2004 and author's calculations. The correlation coefficient ( $r$ ) in each case is between the quality of domestic institutions variable (parliament or police) and the cost of violence threat variable (terrorism or organized crime). Thus, the quality of parliament (or police) in a country is highly correlated with the organized crime variable, but not with the terrorism variable. Questions re threat of violence as for Figure 8; questions re parliament and the police: i) "How effective is your national Parliament/Congress as a law-making and oversight institution? Very ineffective / very effective"; and ii) "Police services can / cannot be relied upon to protect businesses from criminals." 
Figure 11: Relationship of money laundering to domestic corruption: Non-banking money laundering vs. budgetary leakages

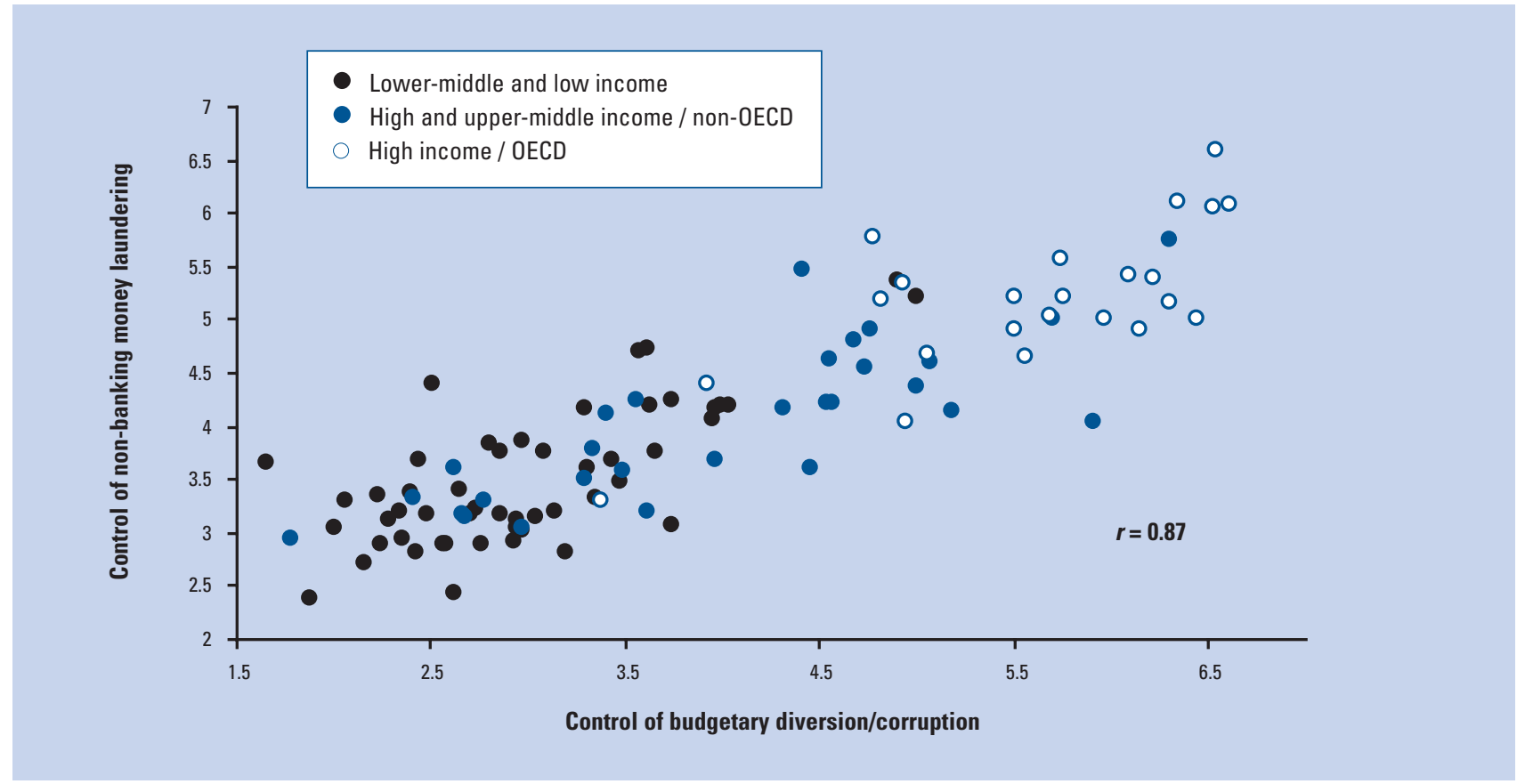

Source: EOS 2004 questions: i) On budget leakages: "In your country, diversion of public funds to companies, individuals or groups due to corruption is common / never occurs." ii) on money laundering: "Money laundering through non-bank and informal financial channels (e.g. exchange or retail shops, exports/imports, gems, real estate) is pervasive / extremely rare."

not shown, it correlates very closely with common crime) - a far cry from the negligible correlation between the costs of the threat of terrorism for the country's enterprise sector and the quality of their domestic institutions (in this case the parliament or the police). ${ }^{22}$

Indeed, the initial empirical analysis suggests that the cost of the terrorist threat for a country seems to be only marginally associated with its own levels of income per capita. In fact, there are countries under threat at every stage of development, ranging from poor countries such as Bangladesh, Nigeria, Indonesia and the Philippines, lowto middle- income countries such as Colombia and Russia, higher-income countries such as Israel and Spain, to the United States at the high end. Conversely, for each one of these stages of development there are examples of countries facing a low terrorist threat. ${ }^{23}$

iv) The complex link between domestic governance, money laundering, and terrorism

The evidence at hand suggests that the link between money laundering and terrorism is far less linear or straightforward than commonly thought, for a number of reasons. First, the financial requirements for terrorism can often be relatively modest; even though it is often linked to laundered money, the financing of terrorism does not necessarily depend on it; thus, for instance, financing can be state-sponsored, or be supported through legitimate businesses. Where the financing of terrorism depends on laundered funds, it does not follow that the culprit is money laundered through the banking sector. To a significant extent, money laundering takes place through informal institutions. In fact, in response to the EOS question on the prevalence of different types of money laundering, the reports of firms from most countries indicate that money laundering through the non-banking sector is at least as prevalent, if not more, as that going through the banking sector. ${ }^{24}$

Terrorism may be construed, therefore, as an extreme global challenge, in that, in most settings, country-specific institutions and measures can have only a limited impact on diminishing the threat of terrorism in that country. However, while it has global links, money laundering, as with organized crime, has a larger domestic component than terrorism, since the quality and strength of domestic governance and institutions are closely related to the prevalence of money laundering in a country. ${ }^{25}$ The empirical evidence at hand supports this contention. First, at a mere 0.16 , and contrary to conventional wisdom, the correlation between the extent of money laundering in a country and the threat of terrorism in that country is strikingly low. By contrast, as we can see in Figure 11, the 
correlation between corruption in the public budget and money laundering is much higher, at 0.87 .

Thus, this initial empirical inquiry suggests that the costs and threat of terrorism cannot be easily explained by focusing on simplistic financial variables, such as money laundering through the banking system, or by merely concentrating on domestic developmental factors. Instead, more promising avenues are offered by probing more deeply, and empirically, into the set of countries where quasi or full-fledged state failure has taken place, at the one extreme, and into the powerful countries of the OECD, on the other, and to their complex interface. In terms of quasi, or actual state failure, a developmental and basic governance approach provides potential insights, complemented by the challenge of non-democratic regimes. Finally, insufficient attention has been paid to the problem of unequal distribution of wealth worldwide; the fact is that worldwide wealth and income inequality across countries is much more severe than the already gross inequities existing within countries.

\section{Conclusions and implications}

In this chapter, we have challenged a number of conventional notions: first, that many manifestations of misgovernance are not subject to measurement, which, in the case of corruption and some other dimensions of governance, has already been challenged for a number of years. ${ }^{26}$ Yet there is still skepticism as to the viability of measurement in many of the political and security dimensions of governance. We have suggested that measurement in these areas is both feasible and desirable. Without such metrics, it is not possible to test many hypotheses and views - often myths not backed by evidence-on these important issues, and this, in turn, results in misguided policy advice. To construct measurable variables and indicators, our empirical tests point to the importance and value of data emerging from reports from the firms on the ground, reflecting de facto reality.

Second, by analyzing the data in these infrequently measured areas of corruption, we both counter a number of popular notions in governance, and portray the mixed governance performance exhibited not only by most countries of the emerging world, but also by the rich countries. We suggest that the undue emphasis on narrow legalism has obscured more subtle yet costly manifestations of misgovernance, such as undue influence by vested interests, and that this form of corruption afflicts emerging economies and rich countries alike. Third, we were led to scrutinize the corporate sector more closely, both domestic and transnational, and its interactions with the public sector, both at home and abroad. The evidence suggests that firms from rich countries operating outside of the OECD appear to behave differently than in their home countries.
This speaks to the need not only for tightening the monitoring and enforcement of the OECD Anti-Bribery Convention, but also for implementing complementary measures to change the incentives for bribery abroad. Transparency mechanisms, utilizing the power of the internet revolution and new survey techniques, hold promise in this respect, as do initiatives such as the World Bank's public delisting of firms practicing bribery in the course of international projects involving Bank funding.

The evidence presented here poses a particular challenge to traditional approaches to the improvement of the investment climate and business development, since it rejects the notion that the firm is the passive investment climate taker of policies shaped and implemented by the all powerful state. Instead, the complex reality is one where many powerful firms play a role in shaping laws and policies of the state and the business environment itself. Thus, corporations are also investment climate makers. This has important policy implications for corporate and national governance measures, impelling us to look beyond the conventional focus on narrow public sector management issues. ${ }^{27}$

We synthesized empirically the relative importance of and links between global and domestic governance aspects of security-i.e. common crime, organized crime and money laundering - and the cost of the terrorism threat. We suggest that the determinants of the costs of threat of terrorism are somewhat more distinct than those for common or organized crime. For crime-related variables, significant headway can be made by focusing on domestic governance and the quality of domestic institutions, while for terrorism, a truly global challenge, the determinants lie elsewhere. With new data, we also suggest a complex-and less than certain-link between money laundering and terrorism. By contrast, we present evidence of a very close link between money laundering and the quality of governance within a country. This implies that we would do well to integrate money laundering issues with those of governance and corruption, rather than seeing them as independent from one another.

Two points in conclusion: first, to emphasize that a number of powerful and rich countries face not only serious problems of undue influence on key public institutions and policies, but also a new set of security threats. The traditionally strong rule-of-law institutions in such countries as the G-7 do not, in themselves, guarantee the existence of a level playing field, nor do they protect against terrorism. Second, the particular focus on rich countries in this year's GCR governance chapter should by no means be construed as signaling an easing of the governance challenge for the emerging economies. On the contrary, the evidence suggests strongly that governance and corruption continues to be a major constraint to development, to the investment climate, and to 
competitiveness in much of the emerging world. Thus, much of the responsibility for the improvement of governance worldwide still lies squarely on the shoulders of the leaders and domestic elites of the emerging countries.

\section{Notes}

1 Daniel Kaufmann is Director of Global Governance at the World Bank Institute. The author acknowledges with appreciation the assistance of Massimo Mastruzzi, Pedro Vicente, Nancy Ackerman, Fatima Latif, the Global Competitiveness team of the World Economic Forum, the research collaboration of Aart Kraay and Joel Hellman, and the suggestions of Mark Nelson and Francesca Recanatini. The views and errors are those of the author, and do not necessarily reflect the official views of the institution. The data are subject to a margin of error and thus not intended for precise ranking of countries.

2 While the OECD currently includes a number of emerging countries in South America and Asia, we refer, for purposes of the analysis in this chapter to the OECD as the original high income members; thus, the terms OECD, rich world, and rich countries, are used interchangeably. More recent entrants to the OECD are classified by the World Bank as belonging to their geographical region and middle income countries.

3 From the EOS country sample, these include Singapore, Taiwan, Hong Kong (China), and Korea.

4 Note that the analysis on these regulations is simply based on the reports by firms on the extent of difficulties they face in this area, inter alia, on how easy or difficult is to start an enterprise. Thus, we do not enter into a normative discussion of the optimal level or type of a regulatory regime; it is understood that some regulations are often warranted, e.g. regarding the environment, child labor, working conditions, etc; however, these are not analyzed here. For further details concerning the empirical work conducted with the data at hand, and for regional and country data details and methodological notes, please see http://www.worldbank.org/wbi/governance/eos04

5 While data resulting from enterprise surveys is obviously subject to a margin of error-in both measurement and in that subjective element in perception which may deviate in some cases from objective facts - the existence of margins of error is by no means limited to survey data. The margin of error for so-called "objective" indicators may be at least as large as for more subjective or perception-based data. See Kaufmann et al. (2004) for details on the problem of margins of error in objective and subjective data.

6 In brief, the essence of how policies and regulations are actually implemented-what firms actually report in the subjective EOS questions-is missed by objective indicators.

7 The coefficient explaining the impact of the de jure complexity of starting a business is reduced by two thirds when the corruption variable is also included, and is rather low. By contrast, the magnitude of the corruption coefficient declines by less than one third, and remains high and very significant in explaining ease of business startup. It should also be noted that similar results emerge if alternative specifications are used. If more than one DB variable is inserted in the same regression, the de jure variables weaken further, due to collinearity. If other indicators are utilized as proxy for the on-theground implementation quality of regulatory policies, such as other corruption variables, or rule-of-law indices, similarly strong results are still evident. In this regard, we should note that indicators measuring rule-of-law in its broad meaning are rather distinct from the objective or de jure variables we discuss here; obviously rule-of-law factors are very important determinants of the business environment as reported by firms.

8 The fact that firms do not single out as high priority obstacles related to the foreign exchange regime or inflation does not necessarily mean an absence of global macro-economic challenges, as illustrated by the potential global dangers and costs-which may be projected into future years-posed by the current twin fiscal and balance-of-payment deficits in the United States.
9 Thus, we see that a high correlation between the $\mathrm{GCl}$ and the EOS data on the extent of access to the Internet in schools, the likelihood of recession this coming year, or the frequency of bribes for tax payments would not be very informative, because those variables are explicit inputs into the calculation of the $\mathrm{GCl}$ sub-indices in the first place (ICT, macro-economic stability and public institutions, respectively). For methodological details on the $\mathrm{GCl}$, see chapter 1.1.

10 The detailed econometric results are available from the author and at http://www.worldbank.org/wbi/governance/eos04

11 The finding that governance and corruption matter significantly for a country's competitiveness is consistent with previous research showing the extent to which governance and corruption has significance for growth, incomes, investment, and social variables. These findings were summarized in our contributions to previous editions of the GCR. Based on the worldwide databank on governance, we emphasized the "400 percent governance dividend," by which we mean that countries which improve their extent of voice and accountability, corruption control, regulatory regime, or quality of rule-of-law institutions by one standard deviation can expect a threeto four-fold increase in per capita incomes in the longer term, and a similar decrease in infant mortality.

12 The top half of the EOS sample in terms of income per capita corresponds exactly to the original countries of the OECD, and the other high- and middle-income countries. It therefore excludes all lowincome countries.

13 Since the indicators at hand have been of an ordinal nature-and thus not cardinal or quantified in absolute terms-they show that, in relative terms, the problem in wealthy countries is, on average, of a lesser magnitude. Furthermore, these indicators often focus on illegal forms of misgovernance, such as bribery.

14 Expanded to mean exerting undue influence on public policy or in receiving a public good, to the particular benefit of the influencing agent or institution. This definition would obviously not encompass (competitive) private sector involvement in the generation or provision of a public good.

15 Thus, for instance, on the corporate side, we do not include some components of corporate social responsibility, such as worker rights or environmental standards, which are sometimes included in interpretations of corporate ethics. Similarly, on the public sector side, the focus is on integrity, honesty and absence of corruption, and not on the efficiency of public service delivery, or of the civil service, or on equality of distribution of income, etc. These are clearly important objectives, intimately associated with ethics and corruption, but are not included within the definition and construction of our more narrowly interpreted index.

16 For fuller exposition of these indices, including its detailed input questions, see the Appendix.

17 The detailed ethics indices for each country are in the Appendix.

18 For details, see United States (1977) and OECD (1999).

\section{Hellman et al 2002.}

20 Similar to the caution expressed in other sections of the data analysis, regarding possible margins of error, the inferences made concerning both the high levels of bribery abroad by many MNCs, as well as the possible improvement over the past year, should be viewed with caution, without ascribing precision to any point estimates. The discussion should be framed in terms of orders of magnitude within a range, and the comparisons and trends presented here should be tested with other such data in the future, as well as in next year's EOS. In this context, it is also to be noted that firms are not asked explicitly to report on the amounts they themselves bribe, but instead the bribes for "firms like yours" or "firms in your industry", depending on the question. For detailed data and results on the levels and trends in bribery abroad, resulting from the analysis of the EOS data, as well as on methodological discussions on these issues, visit http://www.worldbank.org/wbi/governance/eos04 
21 In this limited space, we cannot discuss at any length the literature on the topic of the potential determinants of security threats, and defer to specialists in the field (Arquilla et al., 1999; Barber, 2001; Eizenstat et al., 2004; Norwegian Institute of International Affairs, 2003; Pillar, 2001). We have noted, however, how little, if any, review and analysis of data is done in the expert writings on this topic. It is in this field of metrics where we attempt to make a small initial contribution to the debate.

22 This simple observation ought to be deepened and unbundled in the next stage of the empirical inquiry, since these generalizations may mask important distinctions for different types of countries. For obvious reasons, related to the nature of the challenge, the importance of the quality of domestic institutions for containing terror may be more pronounced in settings such as south Asia or the former Soviet Union than for some G-7 countries.

23 In Figure 9 we saw the sharp differences across countries in this respect, and also the different relative priorities across different challenges within a country.

24 See the evidence in Kaufmann, 2003.

25 Even if there is an obvious and important international component to money laundering, it is also highly dependent on the quality of domestic governance and institutions.

26 In addition to sources already provided on the aggregate governance indicators, see the Transparency International Index on Corruption, at http://www.transparency.org/ More broadly, for governance, a databank inventory of many different data sources is available at http://www.worldbank.org/wbi/governance/govdatasets/index.html

27 See Kaufmann 2002 and 2003 for further details.

\section{References}

Arquilla, J., B. Hoffman, B. Jenkins, I. Lesser, D. Ronfeldt, and M. Zanini. 1999. Countering the New Terrorism. RAND Corporation.

Barber, B. 2001. "Jihad vs, McWorld-Terrorism's Challenge to Democracy." New York: Ballantine, Random House.

Eizenstat, S., J. E. Porter, and J. Weinstein. 2004. On the Brink: Weak States and US National Security. Washington, DC: Center for Global Development.

Hellman, J., G. Jones and D. Kaufmann. 2003. "Seize the State, Seize the Day: State Capture, Corruption, and Influence in Transition Economies." Journal of Comparative Economies, Vol. 31(4). 751-773. Online: http://www.worldbank.org/wbi/governance/pubs/seizestate.html.

Hellman, J. S., G. Jones, and D. Kaufmann. 2002. "Far from Home: Do Foreign Investors Import Higher Standards of Governance in Transition Economies?" Draft. Washington, DC: The World Bank. Online: http://ssrn.com/abstract=386900

Hellman, J., and D. Kaufmann. 2004. "The Inequality of Influence." Building a Trustworthy State in Post-Socialist Transition. J. Kornai and S. Rose-Ackerman, eds. New York, Palgrave Macmillan. Online: http://papers.ssrn.com/sol3/papers.cfm?abstract_id=386901

Kaufmann, D. 2003. "Governance Crossroads." Global Competitiveness Report 2002-2003. P. Cornelius, K. Schwab and M. E. Porter, eds. New York: Oxford University Press. Online: http://www.worldbank.org/wbi/governance/pubs/rethink_gov.html

Kaufmann, D. 2004. "Governance Redux: The Empirical Challenge." In The Global Competitiveness Report 2003-2004. New York: Oxford University Press for the World Economic Forum. Online: http://papers.ssrn.com/sol3/papers.cfm?abstract_id=541322

Kaufmann, D. and A. Kraay. 2002. "Growth without Governance." Economia 3(1). 169-229. Online: http://papers.ssrn.com/sol3/papers.cfm?abstract_id=316861

Kaufmann, D., A. Kraay, and M. Mastruzzi. 2003. "Governance Matters III: Governance Indicators 1996-2002." World Bank Economic Review. September 2004. Washington, DC: World Bank. Online: http://papers.ssrn.com/sol3/papers.cfm?abstract_id=405841
The Norwegian Institute of International Affairs. 2003. "Root Causes of Terrorism Findings." Report of international expert meeting, 9-11 June 2003. Oslo. Online: http://www.nupi.no/IPS/filestore/ Root_Causes_report.pdf

Organisation for Economic Co-operation and Development.1999. "AntiBribery Convention". Paris. Online: http://www.oecd.org/

Pillar, P. 2001. Terrorism and US Foreign Policy. Washington, DC: Brookings Institution Press.

Transparency International Index on Corruption. Online: http://www.transparency.org

United States Department of Justice and Department of Commerce. 1977. "Foreign Corrupt Practices Act Anti-bribery Provisions." Washington, DC. Online: http://www.worldbank.org/wbi/governance/pdf/govredux.pdf

World Bank. 2003. "Doing business in 2004." Washington, DC. Online: http://www-

wds.worldbank.org/servlet/WDS_IBank_Servlet?pcont=details\&eid=0 0009034120031104153559

World Bank. 2004. "World Development Indicators 2004." Washington, DC. Online: http://www.worldbank.org/data/wdi2004/

World Economic Forum. 1998-2004. "Executive Opinion Survey." Global Competitiveness Report. Oxford, UK. 


\section{Appendix: Corporate and public ethics indices}

\begin{tabular}{|c|c|c|c|c|c|c|}
\hline $\begin{array}{l}\text { Ethics indices: Country averages } \\
\text { (Note: Theoretical range of indices } 0-100 \% \text { ) }\end{array}$ & $\begin{array}{l}\text { Corporate Illegal } \\
\text { Corruption } \\
\text { Component } \\
\text { (CICC) }\end{array}$ & $\begin{array}{l}\text { Corporate Legal } \\
\text { Corruption } \\
\text { Component } \\
\text { (CLCC) }\end{array}$ & $\begin{array}{l}\text { (1+2) Corporate } \\
\text { Ethics Index } \\
\text { (CEI) }\end{array}$ & $\begin{array}{l}\text { Public Sector } \\
\text { Ethics Index } \\
\text { (PSEI) }\end{array}$ & $\begin{array}{l}\text { Judicial/Legal } \\
\text { Effectiveness } \\
\text { Index (JLEI) }\end{array}$ & $\begin{array}{l}\text { Corporate } \\
\text { Governance } \\
\text { Index (CGI) }\end{array}$ \\
\hline Algeria & 39.4 & 39.3 & 39.4 & 27.0 & 31.8 & 34.4 \\
\hline Angola & 18.3 & 30.7 & 24.5 & 13.7 & 15.5 & 15.4 \\
\hline Argentina & 30.1 & 16.2 & 23.1 & 21.8 & 12.3 & 36.2 \\
\hline Australia & 92.0 & 50.3 & 71.1 & 78.6 & 89.0 & 88.4 \\
\hline Austria & 82.3 & 57.2 & 69.7 & 67.8 & 83.9 & 78.4 \\
\hline Bahrain & 66.9 & 52.3 & 59.6 & 57.3 & 57.2 & 52.4 \\
\hline Bangladesh & 12.3 & 18.9 & 15.6 & 9.0 & 12.6 & 24.3 \\
\hline Belgium & 75.9 & 54.1 & 65.0 & 64.1 & 68.9 & 85.9 \\
\hline Bolivia & 23.8 & 14.5 & 19.1 & 14.5 & 13.2 & 14.6 \\
\hline Bosnia and Hercegovina & 24.3 & 14.9 & 19.6 & 21.5 & 12.4 & 20.1 \\
\hline Botswana & 54.4 & 47.3 & 50.8 & 55.9 & 60.2 & 45.2 \\
\hline Brazil & 50.9 & 19.9 & 35.4 & 35.2 & 41.5 & 56.3 \\
\hline Bulgaria & 38.6 & 18.4 & 28.5 & 25.2 & 22.4 & 20.5 \\
\hline Canada & 83.3 & 42.9 & 63.1 & 59.7 & 81.6 & 84.4 \\
\hline Chad & 18.7 & 14.4 & 16.6 & 11.6 & 9.6 & 17.3 \\
\hline Chile & 78.6 & 53.5 & 66.0 & 62.9 & 66.1 & 62.2 \\
\hline China & 43.6 & 49.4 & 46.5 & 42.1 & 42.0 & 35.3 \\
\hline Colombia & 51.2 & 22.2 & 36.7 & 22.6 & 30.0 & 42.0 \\
\hline Costa Rica & 56.0 & 24.3 & 40.1 & 34.2 & 47.2 & 47.8 \\
\hline Croatia & 29.9 & 18.5 & 24.2 & 27.7 & 18.2 & 25.4 \\
\hline Cyprus & 55.1 & 36.7 & 45.9 & 54.8 & 63.4 & 31.5 \\
\hline Czech Republic & 32.1 & 30.9 & 31.5 & 35.4 & 37.4 & 42.8 \\
\hline Denmark & 97.1 & 74.7 & 85.9 & 93.6 & 95.3 & 94.8 \\
\hline Dominican Republic & 27.2 & 22.0 & 24.6 & 15.8 & 27.0 & 24.9 \\
\hline Ecuador & 28.5 & 12.3 & 20.4 & 12.1 & 15.0 & 19.9 \\
\hline Egypt & 49.2 & 40.4 & 44.8 & 35.0 & 46.9 & 49.3 \\
\hline El Salvador & 59.4 & 33.9 & 46.7 & 38.2 & 33.9 & 36.3 \\
\hline Estonia & 72.7 & 40.9 & 56.8 & 57.9 & 75.2 & 61.2 \\
\hline Ethiopia & 33.5 & 24.3 & 28.9 & 24.6 & 23.4 & 31.4 \\
\hline Finland & 96.9 & 72.6 & 84.8 & 93.8 & 92.1 & 95.4 \\
\hline France & 79.6 & 39.9 & 59.7 & 61.4 & 76.4 & 73.7 \\
\hline Gambia & 40.6 & 40.2 & 40.4 & 33.1 & 41.6 & 47.7 \\
\hline Georgia & 19.0 & 14.0 & 16.5 & 10.9 & 12.6 & 27.0 \\
\hline Germany & 85.0 & 62.4 & 73.7 & 74.3 & 85.5 & 90.8 \\
\hline Ghana & 45.9 & 47.2 & 46.5 & 36.9 & 64.4 & 52.9 \\
\hline Greece & 47.0 & 26.1 & 36.5 & 39.8 & 55.6 & 44.6 \\
\hline Guatemala & 24.5 & 14.0 & 19.2 & 16.7 & 14.6 & 24.3 \\
\hline Honduras & 24.1 & 11.2 & 17.7 & 11.3 & 17.6 & 16.7 \\
\hline Hong Kong SAR & 90.8 & 59.1 & 75.0 & 82.2 & 82.3 & 69.2 \\
\hline Hungary & 42.8 & 22.5 & 32.6 & 40.7 & 47.1 & 46.7 \\
\hline Iceland & 95.3 & 69.6 & 82.4 & 92.6 & 91.1 & 78.6 \\
\hline India & 39.4 & 29.8 & 34.6 & 31.7 & 59.9 & 55.4 \\
\hline Indonesia & 38.2 & 42.4 & 40.3 & 47.3 & 39.9 & 44.7 \\
\hline Ireland & 77.9 & 42.6 & 60.3 & 64.1 & 77.7 & 80.4 \\
\hline Israel & 80.1 & 36.7 & 58.4 & 64.3 & 72.9 & 73.2 \\
\hline Italy & 47.3 & 34.4 & 40.9 & 33.9 & 40.7 & 32.6 \\
\hline Jamaica & 39.2 & 20.4 & 29.8 & 21.1 & 38.7 & 47.8 \\
\hline Japan & 78.7 & 46.2 & 62.4 & 62.0 & 75.9 & 79.2 \\
\hline Jordan & 66.9 & 59.4 & 63.2 & 58.8 & 67.0 & 38.1 \\
\hline Kenya & 36.1 & 33.4 & 34.8 & 22.3 & 30.4 & 47.4 \\
\hline Korea, (South) & 41.9 & 31.0 & 36.4 & 40.9 & 48.5 & 55.4 \\
\hline Latvia & 36.9 & 20.7 & 28.8 & 32.3 & 33.6 & 43.1 \\
\hline Lithuania & 46.0 & 16.3 & 31.2 & 35.1 & 32.6 & 45.0 \\
\hline Luxembourg & 81.2 & 57.2 & 69.2 & 83.6 & 89.5 & 68.4 \\
\hline Macedonia & 25.2 & 20.5 & 22.8 & 26.0 & 19.4 & 28.8 \\
\hline Madagascar & 20.0 & 15.8 & 17.9 & 16.0 & 19.1 & 32.2 \\
\hline Malawi & 43.5 & 30.4 & 36.9 & 22.6 & 46.6 & 42.3 \\
\hline Malaysia & 66.8 & 47.1 & 56.9 & 58.6 & 77.5 & 66.7 \\
\hline Mali & 31.5 & 24.6 & 28.0 & 18.1 & 27.4 & 31.5 \\
\hline Malta & 63.4 & 38.4 & 50.9 & 46.3 & 66.8 & 39.7 \\
\hline Mauritius & 36.9 & 16.8 & 26.8 & 27.1 & 46.3 & 39.7 \\
\hline Mexico & 40.0 & 22.2 & 31.1 & 23.3 & 29.8 & 38.4 \\
\hline
\end{tabular}


Appendix: Corporate and public ethics indices (cont'd.)

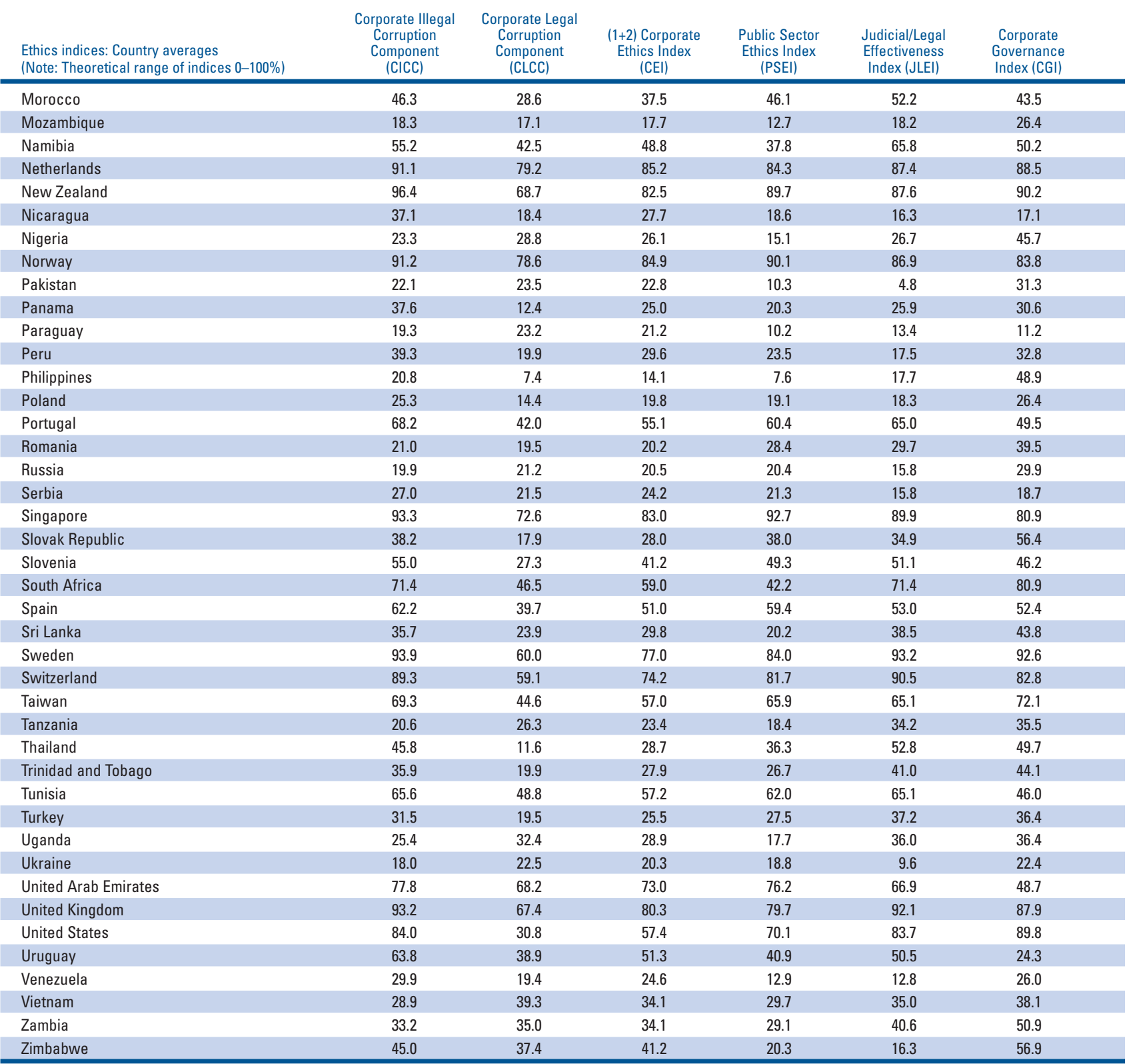

\section{Legend}

CICC (Corporate Illegal Corruption Component): Percentage of firms in the country that give satisfactory ratings (answers 5,6 or 7) to the questions on corporate ethics, illegal political funding, state capture cost, average of frequency of bribery in procurement and active capture, corruption in banking (average of formal money laundering and bribery for loans), and percentage firms reporting 0 percent procurement and administrative bribe shares.

CLCC (Corporate Legal Corruption Component): Percentage of firms in the country that give satisfactory ratings (answers 5,6 or 7 ) to the questions on influencing legal political funding and undue political influence.

CEI (Corporate Ethics Index): Percentage of firms in the country that give satisfactory rating (answers 5, 6 or 7 ) to the questions on index calculated as the average of the percentage of firms' Corporate Illegal Corruption Component and the Corporate Legal Corruption Component.
PSEI (Public Sector Ethics Index): Percentage of firms in the country that give satisfactory ratings (answers 5, 6 or 7 ) to the questions on honesty of politicians, government favoritism in procurement, diversion of public funds, trust in postal office and the average of bribe frequencies for permits, utilities and taxes.

JLEI (Judicial/Legal Effectiveness Index): Percentage of firms in the country that give satisfactory ratings (answers 5, 6 or 7) to the questions on judicial independ ence, judicial bribery, quality of legal framework, property protection, parliament effectiveness and police effectiveness.

CGI (Corporate Governance Index): Percentage of firms in the country that give satisfactory ratings (answers 5, 6 or 7) to the questions on protection of minority shareholders, quality of training, willingness to delegate authority, nepotism and corporate governance. 